Müldür, M. ve Şimşek, N. D. (2020). Türkçe ders kitaplarındaki bilgilendirici metinlerin ve yapılarının incelenmesi üzerine bir araştırma. Ana Dili Eğitimi Dergisi, 8(3), 843-867.

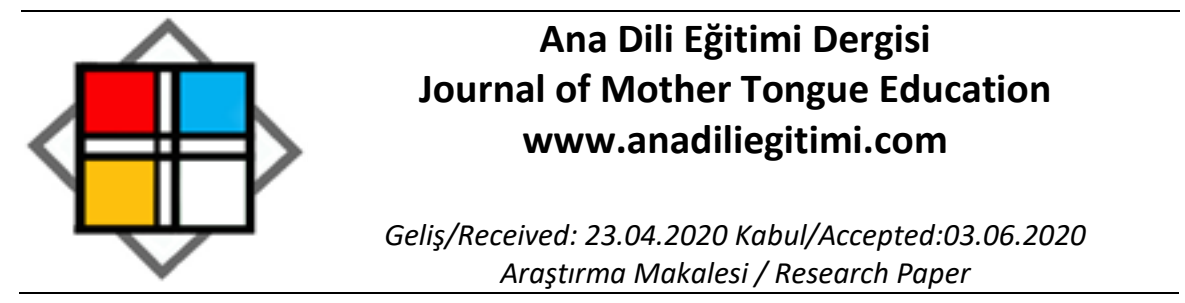

\title{
Türkçe Ders Kitaplarındaki Bilgilendirici Metinlerin ve Yapılarının İncelenmesi Üzerine Bir Araştırma
}

\begin{abstract}
Merve MÜLDÜR*
Nil Didem ŞIMŞEK**

Öz

Bilgilendirici metinler okul ve okul dışı öğrenmelerin temel kaynağını oluşturur. Bilgilendirici metin yapısını bilmek, bir öğrencinin dinlediği veya okuduğu metnin nasıl organize edildiğini anlamasını ve o metni hafızasında tutmasını kolaylaştırabilir. Öğrencilerin bilgilendirici metin yapılarını tanıyabilecekleri en önemli araçların Türkçe ders kitaplarındaki okuma ve dinleme metinlerinin olduğu söylenebilir. Türkçe ders kitaplarında bilgilendirici metin yapılarının her birine önem verilmeli, öğretim sadece bir metin yapısına odaklanarak yürütülmemelidir. Bu araştırmanın temel amacı ders kitaplarında bilgilendirici metinlere ve yapılarına ne oranda yer verildiğini tespit etmektir. Bu araştırmada nitel araştırma yöntemlerinden temel nitel araştırma kullanılmıştır. Çalışma materyalinin belirlenmesinde amaçlı örnekleme yöntemlerinden ölçüt örnekleme yöntemine başvurulmuş, 2019-2020 eğitim öğretim yılında kullanılan altı Türkçe ders kitabı çalışmaya dâhil edilmiştir. Veriler nitel araştırmada veri toplama yöntemlerinden biri olan doküman incelemesi yoluyla toplanmış, betimsel analiz yoluyla analiz edilmiştir. Araştırma sonucunda incelenen tüm ders kitaplarında bilgilendirici metinlere öyküleyici metinlere oranla çok daha az yerildiği görülmüştür. Ayrıca bilgilendirici metin yapılarından en çok tanıtıcı metin yapısına yer verildiği, sıralama, sebep-sonuç, problem çözme ve karşılaştırma metin yapılarına çok sınırlı sayıda yer verildiği tespit edilmiştir. Bilgilendirici metin yapısı çeşitliliğine yer verme açısından Millî Eğitim Bakanlığı tarafından yayımlanan 6. Sınıf Türkçe Ders Kitabının diğer Türkçe ders kitaplarından daha hassas olduğu görülmüştür.
\end{abstract}

Anahtar Kelimeler: bilgilendirici metin, Türkçe ders kitapları, metin yapısı

\section{An Investigation on the Expository Texts Types and their Structural Analyses in Turkish Course Books}

\begin{abstract}
Expository texts are the primary sources of learning in and out of school. Knowing the structure of expository texts may make it easy for a student to understand how the text he is listening to or reading is organized and to keep that text in his memory. It may be stated that the most important instruments that may help students become familiar with the structures of expository texts are the reading and listening texts in their Turkish course books. Importance should be given to each of the expository text structures in the Turkish course books, and teaching should not be carried out by focusing only on one type of text structure. The main goal of this study was to determine to what extent expository text types and knowledge about their structures were included in those course books. In this study, basic qualitative research which is one of the qualitative research methods was used. In determining the materials to be examined, the criterion sampling method, which is one of the purposive sampling methods, was used and six
\end{abstract}

\footnotetext{
* Dr. Öğretim Üyesi, Süleyman Demirel Üniversitesi, Eğitim Fakültesi, Türkçe ve Sosyal Bilimler Eğitimi Bölümü, Isparta, mervemuldur@sdu.edu.tr, ORCID: orcid.org/0000-0002-2595-5749

** Dr. Öğretim Üyesi, Süleyman Demirel Üniversitesi, Eğitim Fakültesi, Türkçe ve Sosyal Bilimler Eğitimi Bölümü, Isparta, nilsimsek@sdu.edu.tr, ORCID: orcid.org/0000-0002-3494-1971
} 
Turkish course books used in the 2019-2020 academic year were thus included in the study. The data were collected through document analysis, which is one of the data collection methods in qualitative research and analyzed through descriptive analysis. The results showed that in all course books expository texts were included much less compared with narrative texts. In addition, it was determined that descriptive expository texts were the most frequent type and that the number of process, cause and effect, problem-solving and comparison and contrast texts very few in number. It was also observed that, in terms of expository text variety, the $6^{\text {th }}$ grade Turkish course book published by the Ministry of National Education included the largest number of text types and examples.

Keywords: expository text, Turkish course books, text structure

\section{Giriş}

Türkçe eğitiminin en temel amacı öğrencilerin anlama ve anlatma becerilerini geliştirmektir. Bu temel amaç doğrultusunda özellikle okuma ekseninde düşünüldüğünde dil eğitimcilerinin en temel isteklerinden birkaçı öğrencilerin okuyarak doğru bir şekilde öğrenmelerini, karşılaştıkları metinlerdeki bilgileri anlamalarını ve bu bilgileri daha önceki bilgileriyle bütünleştirebilmelerini sağlayabilmektir. Bireylere yaşadığı toplumdaki dil kullanımını öğretmek, bireyde dil zevki geliştirmek ve eleştirel okur yetiştirebilmek için metinlerden faydalanılır. Türkçe derslerinin en temel malzemesi metinler ve bu amaçla hazırlanan etkinliklerdir (Dilidüzgün ve Genç, 2019, s. 563). Öğrencilerin metinleri anlayabilmelerinde etkili olan öğrenci kaynaklı, metin kaynaklı, strateji kaynaklı ve görev kaynaklı değişkenler vardır (Meyer, 2003, s. 205). Bu değişkenlerden sadece biri öğrencinin metni anlamlandırabilmesinde yeterli olmaz. Öyle durumlar vardır ki; öğrenci bilişsel, duyuşsal ve bağlamsal açıdan okumaya hazır olabilir hatta strateji ve görev kaynaklı unsurlar ona destek de olabilir ancak öğrencinin karşısına çıkan metin, yapısal özelliği açısından uygun değilse öğrenci metni anlamakta güçlük çekebilir. Bu da okumada istenen hedefe ulaşmayı engelleyebilir. Bu nedenle yetkin bir metin yapısı, metnin anlamlandırılmasındaki temel unsurlardan birini oluşturmaktadır.

Metin yapısı kavramının anlaşılabilmesi için önce metin kavramının ele alınması ve metinsellik ölçütlerinin değerlendirilmesi gereklidir. Metin, iletişimsel bir birim oluşturan yazılı ya da sözlü dilsel bir zincirdir (Ducrot; Schaeffer, 1995, s. 594'ten aktaran: Günay, 2013, s. 40) ama her şeyden önce bir yapıdır (İnceoğlu ve Çomak, 2009, s. 19). Dilsel açıdan bakıldığında metin, "birbirini izleyen, sıralı ve anlamlı bütünler oluşturan cümleler dizisidir" (Günay, 2007, s. 44). Çok farklı düzeylerde, dille iletişimde bulunmak amacıyla oluşturulan anlatma ve anlaşma aracıdır (Aktaş, 2015, s. 15). Başı ve sonu ile kapalı bir yapı oluşturan dilsel göstergelerin art arda geldiği anlamlı yapıdır (Günay 2013, s. 45). "Metin, bilgi, duygu ve düşüncelerin çeşitli biçim, anlatım ve noktalama özelliklerine göre yerleştirildiği yapılardır. Bu yapılara yerleştirme işlemi peş peşe sıralama şeklinde değil, mantıklı bir düzenleme ile gerçekleştirilir" (Güneş, 2013a, s. 606). Dolayısıyla metin, dilin dağarcığındaki sözcüklerin anlamsal olarak birbiriyle ilişkisel düzlemde ortaklık yarattığı bir bütündür.

"Yazılı bir metinde yer alan iletilerin okur tarafından çözümlenebilecek durumda olması için metnin birtakım ölçütlere yapısal olarak uyum göstermesi beklenir. Van Dijk ve Kintsch (1983)'in geliştirdikleri anlama modelinde metnin üç yapısal boyutu arasında ayrım yapılmıştır. Bu boyutlar; küçük yapı, büyük yapı ve üst yapıdır. Bir metnin üst yapısı onun türüyle ilgili genel bir çerçeve sunarken küçük yapı ve büyük yapı metnin içeriğiyle ilgilidir" (İskender ve Yiğit, 2015, s. 451). Üstyapı (superstructure), metinlerin sahip olduğu temel özelliklerle ilgili durumları belirtir. Metin türleri, tonları, tipleri, bir anlatı için belirtilen genel özellikler üstyapı incelemelerinde değerlendirilir (Günay, 2007 , s. 68). Büyük yapı (macrostructure), özetlenebilir metinler üzerinde yapılan bir inceleme biçimidir. Paragraf, bölüm, fasikül, cilt gibi metnin temel bölümleri ya da tutarlılık gibi metin içi genel anlamsal yapının incelenmesi büyük yapının betimlenmesiyle ilgilidir (Günay, 2007, s. 68). Metnin büyük yapısını tanımlarken, metnin ana düşüncesinden ve özetinden faydalanılır. Küçük yapı (microstructure), cümleler arası düzenlemeyi içerir. Bağıntı, yineleme, art gönderim, ön gönderim, eksiltili yapı, eylem zamanı, cümleler arası bağıntı ögeleri, metnin belirticileri, çıkarsamalar gibi durumlar metnin küçük yapısı dâhilinde incelenen unsurlardır (Günay, 2007, s. 67-68). Yazınsal metinlerin anlam katmanlarını yorumlamak için çok bakışlı yaklaşım biçimlerinden faydalanmak gerekir. Hangi tür metin olursa olsun bir metin tek bir yüzey yapıya sahipken, metin türleri arasındaki 
farklara bağı olarak, bir ya da birden fazla derin yapıya sahip olabilir (Aydın ve Torusdağ, 2014, s. 114). Yüzey yapı metnin bağdaşıklık görünümleriyle ilgilidir yani küçük yapıyı temsil eder. Derin yapı da metnin tutarlılık görünümleriyle ilgilidir ve büyük yapıyı temsil eder.

Geleneksel anlama modelleri, anlamı metnin büyük ve küçük yapısına bağlı olarak oluşturmaktadır. Anlamın yukarıdan aşağı oluştuğu modelde, bütünden parçaya doğru bir süreç izlenir. Okur bu şekilde metnin büyük yapısından hareketle daha küçük yapılara yönelir. Anlamın aşağıdan yukarı oluştuğu modelde ise parçadan bütüne giden bir süreç izlenir ve okur, metnin küçük yapısından hareketle büyük yapıya ulaşmaya çalışır (Cornbleet ve Carter, 2001; Woolley, 2011'den akt. İskender ve Yiğit, 2015, s. 452). Anlamın zihinde yapılandırıması sırasında; öncelikle küçük yapıya ilişkin olarak ön anlama gerçekleşir ve birbirini takip eden cümleler arasındaki bütünleştirici yapı şekillenir. Sonrasında büyük yapının aşamalarından son anlama geçilir ve üst düzey öğrenme gerçekleşir. Okur için bir metni okumak güçse, bu durum metnin küçük yapısından kaynaklanır. Örneğin Türkçe yazılmış bir metin için düşünüldüğünde; sondan eklemeli yapısı nedeniyle kelimelerin okunuşu zorsa, cümleler çok uzunsa ve kelime tekrarları varsa vb. bu durumda küçük yapı okuyucuya zorluk çıkarır. Eğer okunan bu Türkçe metnin içeriği yoğunsa, okuyucunun okuma eylemine ilgisi düşük ya da yoksa okuyucunun eğitim düzeyi düşük ya da yetersizse vb. büyük yapı da küçük yapı gibi okuyucuyu zorlayacaktır.

Bir metni, metin yapan birtakım özellikler vardır. Bu özellikler metinsellik veya metin olma ölçütleri olarak ele alınır. Metinsellik, bir metnin oluşması için gerekli koşullar veya metin olmayan cümle gruplarından ayırmak için başvurulan ölçütlerdir (Toklu, 2009, s. 127). Bu ölçütler daha çok De Beaugrande ve Dressler'in (1981) sınıflandırmasından hareketle bağdaşıklık, tutarlıık, amaçlılık, kabul edilebilirlik (ikna edicilik), bilgilendiricilik, duruma uygunluk, metinler arasılık olmak üzere yedi maddede değerlendirilir (Karatay, 2010; Coşkun, 2007). Bunlardan tutarlık metnin her bölümünün birbiriyle olan ilişkisine, metindeki mantıksal değerlendirmelere işaret eden ve metnin daha çok büyük yapısıyla ve üst yapısıyla ilişkili olan bir kavramdır (Günay, 2013, s. 95).

Bir metnin büyük yapısı ve tutarlığı metnin yapısını oluşturan en temel kavramlardır. Metin yapısı terimi bilgilerin nasıl düzenlendiğini ifade eden bir terimdir. Armbruster'e (2004) göre; metin yapısı, fikirlerin dizilişi ve fikirler arasındaki ilişkileri ortaya koyan ve metnin büyük yapısı ve tutarlığıyla ilişkili olan düzenlerdir. "Derin yapıdaki soyut anlamın yüzey yapıda anlaşılır ve etkileyici bir türle sunumu, metnin anlaşılabilirliğini artıran önemli bir unsurdur. Bu sebeple, derin yapı aşamasında metin türünün belirlenmesi gerekmektedir. Ele alınan konunun niteliği, metin türünün belirlenmesinde önemli bir faktördür." (Onan, 2015, s. 100).

Alanyazında metin türleriyle ve metin yapısıyla ilgili yapılan çalışmalarda, metinlerin sınıflandırılması başlı̆ı altında kimi zaman metin yapılarından hareket edildiği dikkati çekmektedir. Genel olarak metnin yapısına göre yapılan kategori; öyküleyici/yazınsal/kurgusal, bilgilendirici/öğretici ve şiir şeklindedir. Akyol ve Tompkins de; metinleri yapısı açısından değerlendiren sınıflamaya göre şiiri hariç tutarak metinleri genel olarak hikâye edici metin yapıları ve bilgilendirici metin yapıları (Akyol, 1999, 2013; Tompkins, 2000) başlıkları altında ele almaktadırlar. Öte yandan bu sınıflandırmaya tartışmacı metin yapıları (Coşkun ve Tiryaki, 2011) katılabilir. Bu çerçevede metin yapıları öyküleyici, bilgilendirici ve tartışmacı metin yapıları olmak üzere üç ana başıı altında ele alınabilir. Söz konusu tasnifin alt sınıflandırmalarından birini oluşturan, okuyucuya bir konu hakkında bilgi vermek veya bir şeyi açıklamak amacıyla yazılan bilgilendirici metinler alan yazında açıklayıcı metinler olarak da anılmaktadır (Piccolo, 1987; Tompkins, 2000).

Bilgilendirici metinler, tipik bir şekilde neden-sonuç, üstünlük-zıtlık ve sorun-çözüm gibi yapılar üzerine inşa edilirler ve içerisinde alt başlıklar, koyu yazılmış yerler ve geniş sözcük dağarcığı barındırırlar (Tok ve Küçük, 2014, s. 236). Bilgilendirici metinler, okurun bilgi evrenini genişletmek amacıyla bir konuda bilgi verme, ele alınan düşünceyi tartışma ve sorgulama yoluyla okura yaşama geçirebileceği bilgiler edindirmeyi amaçlar nitelikte içeriklendirilmektedir (Kuzu, 2004, s. 61). Bilgilendirici ve öğretici metinler okura dünya yaşantısıyla ilgili bilgiler sunan, okuru farklı bakış açılarıyla buluşturan ürünlerdir (Aylanç, 2012, s. 335). Özdemir'e (2002) göre; bir gerçeği, bir düşünceyi, bir gözlem, izlenim veya deneyimin sonucunu okura iletmeyi amaçlayan metinler, bilgilendirici/öğretici metinlerdir (Özdemir 2002, s. 239). Bu yönüyle daha çok düş gücünü harekete 
geçiren ve yeni yaşantı alanları sunan tahkiyeli (olay ağırlıklı) metinlerden ayrılırlar (Aylanç, 2012, s. 336).

Her metnin yapısı içinde var olan işlevler vardır. "Metinler iletişimsel işlevlere sahip ürünlerdir. Bu bağlamda metin yapısı, metnin taşıdığı bu işlev, okuyucular ve anlatıcılar tarafından anlamlandırılabilir ve yorumlanabilir olmalıdır. Bir metnin sadece bir cümleler topluluğu olmaktan çıkıp dilbilimsel anlamda bir metin olabilmesi için içerdiği bazı bilgilerin, ögelerin ve unsurların yinelenmesi, belirlenen olayın sonuca doğru ilerlemesi ve gelişmesi gerekmektedir" (Şeref, Karagöz ve Koç Ardıç, 2020, s. 93). Örneğin, öyküleyici metin yapıları tek bir işlev dâhilinde tek bir yapıdan oluşurken bilgilendirici metin yapıları farklı işlevlere sahip farklı yapılardan oluşmaktadır. Bu doğrultuda bilgilendirici metin yapılarının daha çok Meyer'in (Meyer, 2003; Meyer ve Freedle, 1984) sınıflandırmasından hareketle tanımlayıcı, kronolojik sıralamaya dayalı metinler, problem çözme metinleri, sebep-sonuç metinleri, karşılaştırma metinleri olmak üzere beş başlık altında ele alındığı dikkat çekmektedir. Söz konusu bilgilendirici metin yapıları şu şekilde kategorize edilebilir (Akyol, 2013; Güzel Özmen, 2011; Tok ve Küçük, 2014; Tompkins, 2000; Ülper, 2019):

Sıralamaya dayalı metinler: Bilginin aşamalı olarak sıralandığı metinlerdir. Bu metinlerde birinci, ikinci, önce, sonra, ilk olarak, sonunda gibi anahtar ifadelerden yararlanılır. Bu metinlerin içine bazı kaynaklarda (Meyer, 2003) ayrı bir başlık altında ele alınan listeleme metinleri de dâhil edilebilir.

Tanıtıcı/tanımlayıcı metinler: Bir varlık, kavram, yer vb. bir şeyin özelliklerinin belirtildiği, niteliklerinin sıralandığı metinlerdir. Bu tür metinlerde yazar, konuyu tanıttıktan sonra her paragrafta ele aldığı konunun detaylarına yer verir. Anlatılanları örneklendirerek betimleyerek detaylandırır. Bu metinlerde örneğin, benzer şekilde, üstelik, karakteristikleri, özellikleri gibi anahtar kelimelerden yararlanılır. Bu metinlerin adlandıııışına ilişkin farklı bakış açıları yer almaktadır. Örneğin Akyol (2013) ve Güzel Özmen (2011) tarafından bu metinler tanımlayıcı metinler olarak adlandırılırken Ülper (2019) tarafından açıklama metinleri olarak adlandırılmıştır. Bu adlandırmalar da tanıtıcı metinler ele alınırken göz önünde bulundurulmalıdır.

Karşılaştırma metinleri: Birden fazla durum, kavram, olay vb. arasındaki benzerlik ve/veya farklııkların karşılaştııılmasına dayanan metin yapılarıdır. Bu metinlerde benzer olarak, farklı olarak, ve, veya, buna rağmen, bunun yerine, karşılaştırdığımızda, her ikisi de gibi anahtar kelimelerden yararlanılır.

Sebep-sonuç metinleri: Fikirler nedenleriyle ortaya konur. Nedenlerin ne tür bir sonuca sebep olabileceği üzerinde durulur. Bu metinlerde bu nedenle, bu yüzden, sonuç olarak, çünkü, sonra, sonuç olarak, neden olmak gibi anahtar kelimelerden yararlanılır.

Problem çözmeye dayalı metinler: Bir sorunu çözmek amacıyla ele alınan metinlerdir. Bu tür metinlerde problem ortaya konarak problemin nedenleri ve çözüm yolları üzerinde durulur. Bu metinlerde problem, çözüm yolu, tehlike gibi anahtar ifadelerden yararlanılır.

Bu beş yapıdan oluşan, okul ve okul dışı öğrenmelerin temel kaynağını oluşturan (Armbruster, Anderson ve Ostertag, 1987) bilgilendirici metinler, öğrencilerin özellikle ortaokuldan itibaren karşılarına çıkıp hayat boyunca anlama ve anlatma aracı olarak kullandıkları metinlerdir. Bu metin yapılarına tanıdık olmasının öğrencilerin hayatlarında pek çok önemi vardır. Bilgilendirici metin yapısını bilmek, bir öğrencinin dinlediği veya okuduğu metnin nasıl organize edildiğini anlamasını ve o metni hafızasında tutmasını kolaylaştırabilir. Çünkü Armbruster ve arkadaşlarının (1987) belirttiği gibi metin yapısı metnin önemli noktaların kodlanmasına, hatırlanmasına ve çoğaltılmasına rehberlik eder ve anlamlı öğrenmeyi içeren görevlerde başarı için bir ön koşuldur. Bilgilendirici metin yapısı farkındalığı öğrencinin ana düşünceyi bulma, özetleme ve yazma becerilerinin geliştirilmesi açısından da önem taşımaktadır. Metin yapısı konusunda eğitim verilen öğrencilerin özetleme ve yazma becerilerinin geliştirildiğini gösteren araştırmalar mevcuttur (ör. Armbruster vd. 1987, Raphael, Kirschner ve Englert, 1988). Bu doğrultuda bilgilendirici metin yapısını bilmek kodlama, anlama ve hatırlamada son derece önemli bir rol taşıdığı gibi öğrencilerin konuşarak ve yazarak üretmelerini kolaylaştırma açııından da önem taşımaktadır.

Öğrencilerin bilgilendirici metin yapılarına yönelik farkındalığı sadece dil derslerini etkilememektedir. Öğrenciler fen bilgisi, sosyal bilgiler vb. derslerde de bilgilendirici metin yapıları ile karşı karşıya gelmektedirler. Bilgilendirici metinler tüm derslerdeki başarının sırrı olarak kabul 
edilmektedir (Duke, 2000). Hatta öğrenciler gün içinde okudukları bilimsel dergilerde de (Bilim ve Çocuk Dergisi, Meraklı Minik vb.) bu metinlerle sık sık karşılaşmaktadırlar. Ayrıca teknoloji merkezli yeni dünya düzeniyle birlikte internette onlarca bilgilendirici metne maruz kalmaktadırlar. Hatta youtube üzerinden bir işin nasıl yapılacağı, bir şeyin nasıl kullanılacağı, bir nesneyi, bir yeri tanıtma, bir şeye çözüm bulma gibi konularda türlü metinler üretmekte, bu metin yapılarını farkında olmadan veya olarak bir şekilde kullanmaktadırlar. Derslerde ve günlük hayatta karşılaştıkları metinleri anlayabilmelerinde öğrencilerin bilgilendirici metin yapısı farkındalığına sahip olmaları bu nedenle son derece kıymetlidir.

Metin yapısı farkındalığının bu hususlar çerçevesinde ne denli önemli olduğu düşünüldüğünde öğrencilerin bilgilendirici metin yapılarını tanıyabilecekleri en önemli araçların Türkçe ders kitaplarındaki okuma ve dinleme metinlerinin olduğu söylenebilir. Metinler bireyin dil ile iletişim kurmasını sağlamakta ve dili somutlaştırmaktadır. Bu nedenle dil eğitimi genellikle metinler merkezinde yapılmaktadır (Çiftçi, Çeçen ve Melanlıoğlu, 2007). Ana dili öğretimi sürecinde araç olarak kullanılan bu metinler aynı zamanda toplum için ortak bir hafıza oluşturmanın da önünü açar. "Bilgilendirici ve öğretici metinlerde ele alınan konular, öğrenciye sadece Türk dilinin yapısı, kullanım şekilleri hakkında bilgi vermez, aynı zamanda öğrencilerin farklı alanlarındaki bilgilerini de destekler. Onların sözel zekâ gelişimlerine katkı sağlayarak algılama, yorumlama ve eleştirel düşünme becerilerini geliştirir. 'Birey, toplum, doğa ve evren'in anlamlandırılmasında ve yaratıcılık bağlamında Türkçe dersinde okunan metinlerin önemli yeri vardır" (Aylanç, 2012, s. 344).

Metinlere işlevleri açısından da bakıldığında "kullanım işlevli metinler, hedef kitlenin derste öğrendiklerini günlük hayatında uygulayabilmesini sağlayan metinlerdir. Bu metinlerle hedef kitlenin günlük hayatta karşılaşılan durumları, sorunları anlaması ve bunlara yönelik çözümleri doğru ifade etmesi amaçlanır. Bu aşamada ilanlar, resmi yazılar, haritalar, kullanım kılavuzları gibi metinler tercih edilir. Bilgi iletici metinler, hedef kitlenin bilgiyi anlama, değerlendirme ve yorumlama becerilerinin geliştirilmesinde kullanılır" (Üstten ve Haykır, 2019, s. 1639-1640). Pek çok araştırma bilgilendirici metin yapısı öğretiminin anlama ve anlatma üzerinde olumlu etkisi olduğunu göstermektedir. Metin yapısı öğretiminin anlama üzerinde olumlu bir etkisinin olduğunu ve hatırlamayı kolaylaştırdığını gösteren (ör. Armbruster vd., 1987; Hall, Sabey ve McClellan, 2005; Williams, 2005) araştırmalar olduğu gibi yazmayı kolaylaştırdığını gösteren araştırmalar (ör. Taylor \& Beach, 1984; Miller ve Lignugaris-Kraft, 2002) da vardır. Bütün bu vurgulananlar ders kitaplarında bilgilendirici metinlere yer verilmesinin ne denli önemli olduğunu ortaya koymaktadır.

Ders kitaplarında yer alan bilgilendirici metinlerin belirli bir düzen içerisinde yazılmış metinler olmaları gereklidir. İnsanların daha çok belirli bir düzende yazılan metinleri, dağınık olarak sunulan bilgilerden daha kolay bir şekilde anlayıp daha sonra da hatırlayabilecekleri (Meyer, 2003) göz önünde bulundurulduğunda bu durum daha da önem kazanmaktadır. Dolayısıyla bilgi iletici/öğretici metinlerin metin yapısı açısından bağdaşık ve tutarlı olması gerekir. Aksi takdirde, hedeflenen bilgi mesajının alıcı tarafından anlaşılmasında ve değerlendirilmesinde eksiklik oluşacaktır. Ayrıca öğrenciler bilgilendirici metinlerin bütün yapılarına aşina olacak şekilde öğretim görmelidirler (Piccolo, 1987). Öğrenciler hayatları boyunca Türkçe derslerinde, başka derslerde ve gerek toplumda gerek teknolojik ortamı da kapsayan günlük hayatlarında bilgilendirici metinlerin farklı yapılarıyla sıklıkla karşılaştıkları ve bu türde metinler ürettikleri için bilgilendirici metin yapılarının her birine önem verilmeli, öğretim sadece bir metin yapısına odaklanarak yürütülmemelidir. Bu nedenle ders kitaplarında da bilgilendirici metinlerin farklı yapılarına yer verilmelidir. Bu doğrultuda bu araştırmanın temel amacı Türkçe ders kitaplarında bilgilendirici metinlere ve yapılarına ne oranda yer verildiğini tespit etmektir. Bu bağlamda araştırmada şu sorulara cevap aranacaktır:

1. Türkçe ders kitaplarında bilgilendirici metinlere ne oranda yer verilmektedir?

2. Türkçe ders kitaplarında tanıtıcı (tanımlayııı/açıklama) metin yapısına ne oranda yer verilmektedir?

3. Türkçe ders kitaplarında sıralayıcı metin yapısına ne oranda yer verilmektedir?

4. Türkçe ders kitaplarında karşılaştırma metin yapısına ne oranda yer verilmektedir?

5. Türkçe ders kitaplarında neden-sonuç metin yapısına ne oranda yer verilmektedir?

6. Türkçe ders kitaplarında problem çözme metin yapısına ne oranda yer verilmektedir? 
Mevcut araştırmanın Türkçe Ders Kitaplarındaki durumunu tespit ederek ders programı hazırlayan yetkililere, kitap yazarlarına yol göstereceği düşünülmektedir. Ayrıca ders kitaplarındaki metinlere ilişkin yapılan araştırmalarda metinlerin daha çok edebî tür (ör. Baş, 2003; Kolaç, 2009; Orakçı ve Arhan, 2019; Özbay ve Çeçen, 2012; Solak ve Yaylı, 2009; Söylemez, 2019), metin türü farkındalığı (ör. Kıbrıs, 2019), dinleme metinlerinin tür dağılımı, öğrenciye görelik (ör. Turan Siviş ve Emiroğlu, 2020), metin tasnifinde öğretmen ve öğretmen adayı görüşleri (ör. Kaya ve Kardaş, 2019), yazınsallık ve bilgi (ör. Somuncu, 2019), edebî zevk ve hoşa giderlik (Coşkun ve Çetinkaya, 2020) gibi açılardan incelendiği görülmektedir. Metin yapıları açısından yapılan çalışmaların (ör. Temizkan, 2016; Sulak, 2009) sınırlı olduğu tespit edilmiştir. Bu bağlamda alanyazında var olan boşluğun doldurulması hedeflenmektedir. Ayrıca bu araştırmada her sınıf kademesindeki ders kitabının incelenmesinin çalışmanın kapsayıcılığı açısından önemli olduğu düşünülmektedir.

\section{Araştırmanın Modeli}

\section{Yöntem}

Bu araştırmada nitel araştırma yöntemlerinden temel nitel araştırma kullanılmıştır. Diğer nitel araştırmalarda olduğu gibi verilerin gözlem, görüşme veya doküman analizleri ile toplanıp araştırmacı tarafından bir olguyu anlamak ve açıklamak için yorumlanması olarak ifade edilen temel nitel araştırma, eğitim alanında kullanılan en yaygın nitel araştırma biçimlerindendir (Merriam, 2013). Bu araştırmada Türkçe ders kitaplarındaki bilgilendirici metinler ve yapılarının doküman incelemesi yoluyla elde edilen verilere dayanarak ortaya konması amaçlandığından temel nitel araştırma yöntemi tercih edilmiştir.

\section{Çalışma Materyali}

$\mathrm{Bu}$ araştırmada çalışma materyalinin belirlenmesinde amaçlı örnekleme yöntemlerinden ölçüt örnekleme yöntemine başvurulmuştur. Ölçüt örneklemede önceden belirlenmiş bir dizi ölçütü karşılayan durumlar çalışılır. Söz konusu ölçüt araştırmacı tarafından oluşturulabilir veya daha önceden hazırlanan bir ölçüt listesi kullanılabilir (Yıldırım ve Şimşek, 2016, s. 122). Bu araştırmada sınırlı̆̆ı belirleyebilmek ve nesnelliği, kapsayıcılığı sağlayabilmek adına araştırmacılar tarafından belirlenen üç ölçüt gözetilmiştir. Türkçe ders kitaplarının belirlenmesinde öncelikli olarak yıl sınırlandırılmasına gidilmiş; güncel olması nedeniyle 2019-2020 eğitim öğretim yılındaki ders kitaplarının incelenmesine karar verilmiştir. İkinci olarak kapsayıcılığı sağlayabilmek için bütün kademelerdeki (5-6-7-8. sınıflar) Türkçe ders kitaplarının incelenmesi ölçütü belirlenmiştir. Son olarak da nesnelliği sağlayabilmek için her sınıf kademesinden bir özel bir de MEB yayınevine ait ders kitaplarının incelenmesine karar verilmiştir. Bununla birlikte 2019-2020 Eğitim-Öğretim yılında 5 ve 8. sınıflarda hem özel hem de MEB yayınlarına ait ders kitabının olmadığı, yedinci sınıflarda ise ikisi MEB yayınlarına biri özel yayınevine ait olmak üzere üç yayınevine ait ders kitabı kullanıldı̆̆ı tespit edilmiştir (MEB, 2019). Bu nedenle beşinci ve sekizinci sınıflarda MEB'in belirlediği ders kitabı çalışmaya dâhil edilmiştir. Altıncı sınıflarda MEB'in belirlediği iki ders kitabı çalışmaya dâhil edilmiştir. Yedinci sınıflarda da biri MEB yayınlarına diğeri özel yayınevine ait olmak üzere iki ders kitabı çalışmaya dâhil edilmiştir. Söz konusu bu ölçütler kapsamında araştırmanın çalışma materyali Tablo 1 'de sunulmuştur.

Tablo 1.

Çalış̧ma Materyaline iliş̧kin Bilgiler

\begin{tabular}{llll}
\hline $\begin{array}{l}\text { Sınıf } \\
\text { Seviyesi }\end{array}$ & Çalışma Materyali & $\begin{array}{l}\text { Metin İçi } \\
\text { Kısaltması }\end{array}$ \\
\hline 5. Sınıf & $\begin{array}{l}\text { Anıttepe Yayınları Ortaokul ve İmam Hatip } \\
\text { Ortaokulu Türkçe 5. Sınıf Ders Kitabı }\end{array}$ & AYT5 \\
& $\begin{array}{l}\text { Ekoyay Yayınları Ortaokul ve İmam Hatip } \\
\text { 6. Sınıf }\end{array}$ & EYT6 \\
& Ortaokulu Türkçe 6. Sınıf Ders Kitabı & \\
\hline 6. Sınıf & MEB Yayınları Ortaokul ve İmam Hatip & MEBYT6 \\
\hline
\end{tabular}




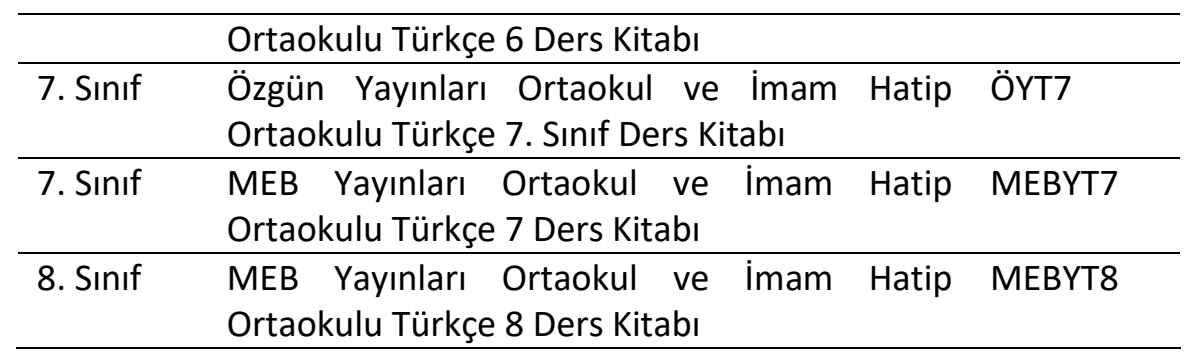

Çalışma materyallerinde sekiz temada yer alan bütün metinler (okuma, dinleme ve serbest okuma metinlerinin hepsi) çalışmaya dâhil edilmiş, bu doğrultuda toplamda 240 metin çalışmanın esas kapsamını oluşturmuştur.

\section{Verilerin Toplanması ve Analizi}

$\mathrm{Bu}$ araştırmanın verileri nitel araştırmada veri toplama yöntemlerinden biri olan doküman incelemesi yoluyla toplanmıştır. Doküman incelemesi araştırılması hedeflenen olgu ve olaylar hakkında bilgi içeren yazılı materyalin analizini kapsar Eğitim alanında en çok kullanılan materyaller arasında ders programları, ders kitapları sıralanabilir. (Yıldırım ve Şimşek, 2016, s. 189). Araştırmada çalışma materyallerinde belirtilen ders kitaplarındaki metinler bilgilendirici metinler ve yapıları açısından incelenmiştir.

Araştırmada nitel araştırma veri analizlerinden biri olan betimsel analiz yöntemi kullanılmıştır. Betimsel analiz yönteminde veriler daha önceden belirlenen temalara göre özetlenir ve yorumlanır. Araştırmacı verileri araştırma soruları ve boyutlarına uygun olarak da sunabilir (Yıldırım ve Şimşek, 2016, s. 239). Mevcut araştırmada bilgilendirici metinlerin dağılımı sunulurken araştırmanın kuramsal bölümünde yer alan metin yapısı sınıflamasından yararlanılmış; metinler şiir, öyküleyici metin, bilgilendirici metin ve tartışmacı metin sınıflandırmasına göre incelenmiştir. Bilgilendirici metinler incelenirken de yine kuramsal bölümde belirtilen beşli sınıflandırmadan yararlanılmıştır. Bu doğrultuda bilgilendirici metin yapıları sıralama, tanıtıcı, sebep-sonuç, problem çözme ve karşılaştırma sınıflandırması bağlamında ele alınmıştır. Öte yandan veriler analiz edilirken karma yapılara rastlandığı için bunlar da bulgular kısmında sunulmuştur.

\section{Geçerlik ve Güvenirlik}

Nitel araştırmalarda önemli konulardan biri de araştırmanın geçerliği ve güvenirliğidir. Araştırmanın geçerlik ve güvenirliğini artırmak için Türkçe ders kitaplarındaki metinler öncelikle iki araştırmacı tarafından bağımsız bir şekilde incelenmiş, ardından kodlayıcılar arası güvenirlik katsayısı hesaplanmıştır. Araştırmanın güvenilirlik hesaplaması için Miles, Huberman ve Saldana'nın (2014) önerdiği "Güvenirlik = Görüş Birliği / (Görüş Birliği + Görüş Ayrılı̆̆ı)" güvenirlik formülü kullanılmıştır. Araştırmacıların 13 metinde uzlaşamadığı, 227 metinde uzlaştığı tespit edilmiştir. Buna göre araştırmanın güvenirliği \%95 olarak hesaplanmıştır. Güvenirlik hesaplarının \%70'in üzerinde çıkması, araştırma için güvenilir kabul edildiği için (Miles, Huberman ve Saldana, 2014) mevcut araştırma güvenilir kabul edilmiştir. Uzlaşılamayan metinler için iki Türkçe öğretmeninin görüşüne başvurulmuştur. Nitel araştırmalarda araştırmanın geçerliğini artırmak için aktarılabilirliğe de önem verilmelidir. Nitel araştırmalardaki aktarılabilirlik ayrıntılı betimleme ve amaçlı örnekleme ile sağlanabilir (Yıldırım ve Şimşek, 2016). Bu araştırmada araştırmanın aktarılabilirliğini artırmak için bulgular sunulurken ders kitaplarından metin örneklerine yer verilmiştir. Ayrıca amaçlı örnekleme yöntemlerinden ölçüt örnekleme yöntemine başvurulmuştur.

\section{Bulgular}

Çalışmanın kuramsal çerçevesinde yer alan bilgilerden hareketle bilgilendirici metinler genel olarak beş başlık (sıralama, tanıtıcı, sebep-sonuç, problem çözme karşılaştırma) altında ele alındığı için bulguların sunumunda bu beş başlığa yer verilmiştir. Ayrıca ders kitaplarında bilgilendirici metinlere ne ölçüde yer verildiğini göstermek amacıyla diğer yapılardaki (öyküleyici ve tartışmacı) 
metinler ve şiir dağılımı incelenmiş, bunlara ilişkin veriler de bulgular kısmında sunulmuştur. Bunların yanı sıra araştırma kapsamında karma yapılı metinlere rastlandığı için bulgular kısmında bunlara da yer verilmiştir. Araştırma kapsamında incelenen altı kitaba yönelik bulgular her kitap için ayrı ayrı sunulmuştur. Bulguların son maddesinde çalışmaya dâhil edilen tüm kitaplardaki durum da ortaya konulmuştur.

\section{AYT5 Ders Kitabı'ndaki Bilgilendirici Metinler ve Yapılarına ilişkin Bulgular}

AYT5 Ders Kitabı'ndaki bilgilendirici metinler ve yapılarının dağılımına ilişkin bulgular, Tablo 2 , Şekil 1 ve Şekil 2'de sunulmuştur.

Tablo 2.

AYT5 Ders Kitabı'ndaki Bilgilendirici Metin Yapıları

\begin{tabular}{|c|c|c|}
\hline Bilgilendirici Metin Yapısı & $f$ & Metinler \\
\hline Siralama & 1 & Sokak \\
\hline Tanıtıcı & 8 & $\begin{array}{l}\text { Hoşça Kalın, Güle Güle } \\
\text { Anadolu'da Konukseverlik } \\
\text { Okland Adası } \\
\text { Ali Kuş̧̧ } \\
\text { Büyüklere Saygı } \\
\text { Barkod } \\
\text { Akıllı Ulaşım Sistemleri } \\
\text { Aziz Sancar }\end{array}$ \\
\hline Sebep-Sonuç & 2 & $\begin{array}{l}\text { Spor ve Bedenimiz } \\
\text { Sosyal Medya Psikolojinizi Etkiliyor }\end{array}$ \\
\hline Problem Çözme & - & - \\
\hline Karsılasstırma & - & - \\
\hline 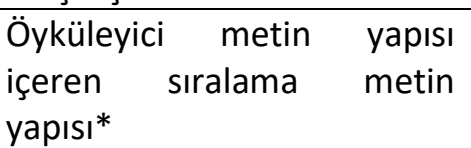 & 1 & Dumlupınar Savaşı \\
\hline
\end{tabular}
için Tablo 2'de bu metinlere de yer verilmiştir.

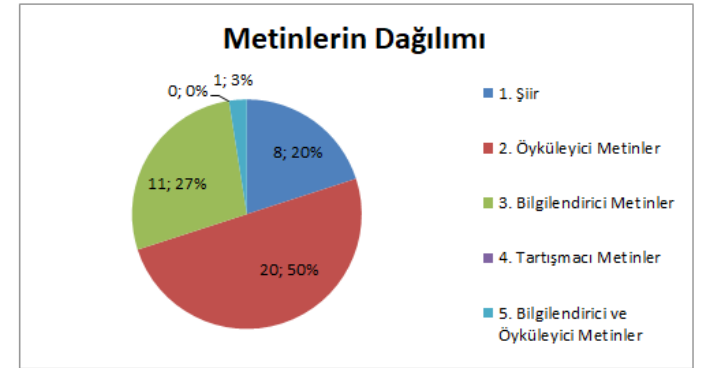

Şekil 1. AYT5 Ders Kitabı'ndaki Metinlerin Dağııımı Şekil 2. AYT5 Ders Kitabı'ndaki Bilgilendirici Metinlerin Yapılarına Göre Dağılımı

Şekil 1'de görüldüğü gibi AYT5 Ders Kitabı'nda yer alan 40 metin (24 okuma, 8 dinleme, 8 serbest okuma metni) incelendiğinde bu metinlerden $\% 20$ 'sinin ( $f=8)$ şiir, $\% 50$ 'sinin ( $f=20)$ öyküleyici metin, \%27'sinin ( $f=11)$ bilgilendirici metin, \%3'ünün $(f=1)$, bilgilendirici ve öyküleyici metin yapılarının birlikte kullanıldığı karma metinlerden oluştuğu görülmektedir. Tablo 2 ve şekil 2'de görüldügü gibi araştırmanın esas amacını oluşturan bilgilendirici metinler açısından bakıldığında daha çok tanıtıcı metin yapılarına $(f=8)$ yer verildiği, sebep-sonuç $(f=2)$, sıralayıcı $(f=1)$ metin yapılarına sınırlı sayıda yer verildiği, problem çözme ve karşılaştırma metin yapılarına ise hiç yer verilmediği görülmüştür. 
Gezi türünde kaleme alınmış olan Okland Adası tanıtıcı metin yapısına örnek olarak gösterilebilir. Illgili metinde adanın bina ve yapıları, park yerleri, tarihteki yeri, sanat anlayışı ve ticareti gibi özellikleri tanıtılmaktadır. Bu metinde tanıtıcı metin yapılarında görüldüğü gibi önce Yeni Zelanda'nın en önemli kentlerinden biri, yelkenler kenti olarak da anılan güzel bir ada, dünyanın en huzurlu kentlerinden biri olan Okland adası konu olarak sunulmuş, ardından Okland Adası'yla ilgili belirtilen ayrıntılara (bina ve yapıları, park yerleri vb.) yer verilmiştir. Okland Adası betimlemelerden yararlanılarak açıklanmıştır. Metinde "da, ama, gibi, -den biri olarak, için, ve, anlaşılan, en, hem ...hem, özellikle" gibi bağlama ögelerinden ve belirleyici sözcüklerden yararlanılmıştır.

Sebep-sonuç metin yapısıyla kaleme alınan Spor ve Bedenimiz metninde sporun faydaları ve ortaya çıkaracağı üzerinde durulmuştur. Bu bağlamda yazar spor yapmanın bireyin vücudunu nasıl etkileyeceğinden, sporun bireyin vücudunu güçlü ve sağlıklı kılacağından, böylece normal fiziksel etkinlikleri kolay yapabileceğinden, kendine saygısı ve güveninin artacağından bahsetmiştir. Spor sayesinde bireyin beden sağlığının gelişeceğine, olası hastalıkların önüne geçilebileceğine, uzun ve mutlu yaşanabileceğine değinilmiştir. Bu doğrultuda metinde spor yapmak neden, bahsi geçen bu özellikler de sonuç olarak sunulmuştur. Metinde "çünkü, sonuç olarak, böylece, ayrıca" gibi bağlama ögelerinden yararlanılmıştır.

Bir dinleme metni olan Sokak metninde de bir babanın çocuğuna verdiği nasihatler listelenerek sunulmuş ve böylece sıralayıcı bir metin yapısı oluşturulmuştur. "Sokakta yürürken dikkat et.", "Sokak herkesin evidir, bunu unutma.", "Sokakta bir ihtiyara, kollarında çocuk bulunan bir kadına, koltuk değnekli bir sakata... rastladığın zaman onlara saygı ile yol vermek zorundasın.", "Kendisine bir arabanın çarpma tehlikesini gördüğün kimse bir yetişkinse haber ver, çocuk ise çekip kurtar.", "iki çocuk kavga ediyorsa ayır.", "Kavgacılar küçük değilse kalpleri yaralayan ve katılaştıran kaba davranışları görmemek için oradan uzaklaş.", "Yolunu senden soran bir yolcuya her zaman saygılı cevap ver.", "Herkese sırıtma.", "Gereksiz yere koşma, bağırma.", "Sokağa saygı duy." gibi türlü öğütler metin boyunca listelenerek verilmiştir. Bu bağlamda metinde emir kipiyle oluşturulmuş yönergeler sunularak dilsel yapı güçlendirilmiştir.

AYT5 ders kitabında dikkati çeken özelliklerden biri de karma yapılı metinlerin görülmesidir. Dumlupınar Savaşı metninde yazar, Dumlupınar Savaşı'nda olan olayları kronolojik sıralamaya yer vererek anlatmıştır. Bu metinde yazarın esas amacı okuyucuları Dumlupınar Savaşı hakkında bilgilendirmektir. Yalnız yazar bunu yaparken hem kronolojik sıralamadan hem de öykülemeden yararlanmıştır. Kronolojik sıralamaya yer veren yazar 23 Ağustos 1992, 26 Ağustos 1922, 30 Ağustos 1922 ve 9 Eylül 1922'de yapılanları kronolojik olarak okuyucuya aktarmıştır. Ayrıca bilgi vermeyi göz önünde bulundururken Mustafa Kemal'in eylemlerine de yer vererek öyküleme unsurlarını da metne dahil etmiştir. "Konya'ya gitti.", "... ileri gelen komutanları çevresinde topladı.", "Gün ağarırken ... bir saldırı başladı", "Toplar patıyor; Mehmetçikler ... Yunan siperlerini yıldııım gibi aşıyordu." gibi cümleler öyküleyici metnin dilsel göstergeleridir.

\section{EYT6 Ders Kitabı'ndaki Bilgilendirici Metinler ve Yapılarına ilişskin Bulgular}

EYT6 Ders Kitabı'ndaki bilgilendirici metinler ve yapılarının dağılımına ilişkin bulgular, Tablo 3, Şekil 3 ve Şekil 4'te sunulmuştur.

Tablo 3. EYT6 Ders Kitabı'ndaki Bilgilendirici Metin Yapıları

\begin{tabular}{lll}
\hline Bilgilendirici Metin Yapısı & $f$ & Metinler \\
\hline Sıralama & - & - \\
\hline Tanıtıcı & 5 & İyilik Üzerine \\
& & Öğretmenimin Mektubu \\
& Büyük Keşifler \\
& İnsansı Robotlarla Tanışalım \\
& & Mozart'ın Müziği \\
\hline Sebep-Sonuç & - \\
\hline
\end{tabular}




\begin{tabular}{|c|c|c|c|}
\hline Problem Çözme & & - & - \\
\hline Karşılaştırma & & - & - \\
\hline $\begin{array}{l}\text { Öyküleyici metin } \\
\text { içeren tanıtıcı } \\
\text { yapısı* }\end{array}$ & $\begin{array}{l}\text { yapısı } \\
\text { metin }\end{array}$ & 2 & $\begin{array}{l}\text { Meşeler } \\
\text { Oyuncak }\end{array}$ \\
\hline
\end{tabular}

*Bu metinler Şekil 3'teki bilgilendirici ve öyküleyici metinlerin içinde olduğu ve tanıtıı metinleri de kapsadığı için Tablo 3'te bu metinlere de yer verilmiştir.

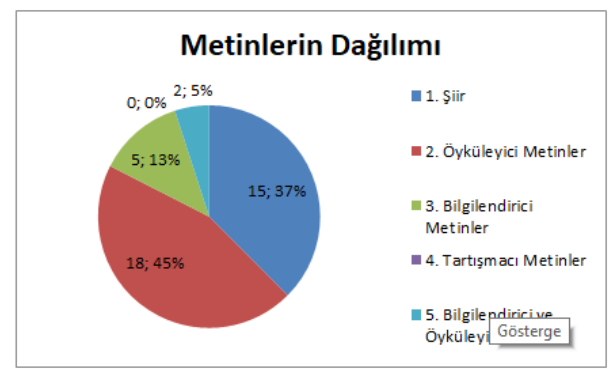

Şekil 3. EYT6 Ders Kitabı'ndaki Metinlerin Dağıımı

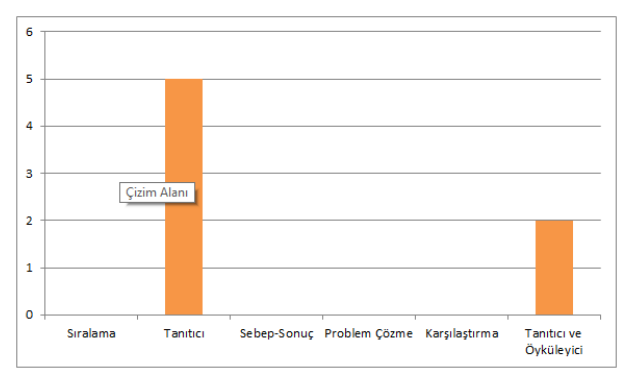

Şekil 4. EYT6 Ders Kitabı'ndaki Bilgilendirici Metinlerin Yapılarına Göre Dağııımı

Şekil 3'te görüldüğü gibi EYT6 Ders Kitabı'nda yer alan 40 metin (24 okuma, 8 dinleme, 8 serbest okuma metni) incelendiğinde bu metinlerden \%37'sinin ( $f=15)$ şiir, \%45'inin ( $f=18$ ) öyküleyici metin, \%13'ünün ( $f=5)$ bilgilendirici metin, \%5'inin de $(f=2)$ hem öyküleyici hem de bilgilendirici metin yapısının birlikte kullanıldı̆ı karma metinlerden oluştuğu görülmektedir. Tablo 3 ve Şekil 4'te görüldüğü gibi araştırmanın esas amacını oluşturan bilgilendirici metinler açısından bakıldığında daha çok tanıtıcı metin yapılarına $(f=5)$ yer verildiği, sıralama, sebep-sonuç, problem çözme, karşılaştırma metin yapılarına hiç yer verilmediği görülmektedir.

Bilgilendirici metinlerden sadece tanıtıcı metin yapısının kullanıldığı bu ders kitabında yer alan metinlerden biri olan Mozart'ın Müziği başıklı dinleme metninde Mozart, metnin başında kısaca William Kroc ile karşılaştırılmıştır. Mozart'ın müziği de konu olarak sunulmuştur. Ardından tanıtıcı metinlerde görüldüğü üzere metin içinde Mozart’ın müziğine ilişkin özellikler, ayrıntılı bir şekilde açıklanmıştır. Bu bağlamda Mozart'ın ürettiği müzik biçimleri, dinlenmesi gereken şaheserleri, operaları, başarılarının sırları, konçertolarından örnekler, eserlerinin konusu ile müziği arasındaki bağlantı gibi özellikler anlatılmıştır. Anlatım örneklendirmeden yararlanılarak güçlendirilmiştir. Metinde "bir de, ...-dir (muhteşemdir vb.), doğruya doğru, ama, Mozart'ın müziğinde .... vardı, mesela, işte" gibi belirleyici ifadelerden yararlanılmıştır.

EYT6 ders kitabında dikkati çeken özelliklerden biri de karma yapılı metinlerin görülmesidir. Bir anlatım biçimi ve düşünceyi geliştirme yolu olmanın ötesinde iki metinde (Meşeler ve Oyuncak) hem tanıtıcı metin yapısının hem de öyküleyici metin yapısının iç içe geçtiği görülmektedir. Örneğin Meşeler metninde meşelerin diğer ağaçlar içindeki yeri, görüldüğü yerler, toprağa sıkıca tutunan bir bitki oluşu, meşelerin yetişme koşulları gibi özellikleri beş paragraf tanıtıldıktan sonra yazarın köyündeki meşelerle bağlantı kurulmaktadır. Yazar bu bölümden sonra da kendi köyündeki meşelerin tarihî süreçlerini, yetişme koşullarını, türlerini tanıtır. Ancak "Meşeler için bu yazıyı yazmamın amacı bunları söylemek değildi. Çocukluk anılarımı süsleyen gür yapraklı ulu mu ulu bir meşe ağacını anlatmak istiyordum. Söz buralara geldi." cümleleriyle kendi çocukluğundaki ulu meşe ağacını betimlemeye başlar. Ardından ana karakterlerinden Ismayıl'la ilgili başlarından geçen bir olayı tahkiye eder. Böylece bu metinde yazarın daha çok tanıtıcı metin yapısını kullandığı görülmekle birlikte öyküleyici metin yapısından da yararlandığı tespit edilmiştir. 


\section{MEBYT6 Ders Kitabı'ndaki bilgilendirici metinler ve yapılarına ilişkin bulgular}

MEBYT6 Ders Kitabı'ndaki bilgilendirici metinler ve yapılarının dağılımına ilişkin bulgular, Tablo 4, Şekil 5 ve Şekil 6'da sunulmuştur.

Tablo 4.

MEBYT6 Ders Kitabı'ndaki Bilgilendirici Metin Yapıları

\begin{tabular}{|c|c|c|}
\hline Bilgilendirici Metin Yapısı & $f$ & Metinler \\
\hline Siralama & - & - \\
\hline \multirow[t]{11}{*}{ Tanıtıcı } & 11 & 15 Temmuz \\
\hline & & Çanakkale Türküsü'nün Hikâyesi \\
\hline & & $\begin{array}{l}\text { Insanlar Zamanı Eskiden Nası } \\
\text { Ölccerdi? }\end{array}$ \\
\hline & & Bak Postacı Geliyor Selam Veriyor \\
\hline & & Atatürk'ün Geometri Kitabı \\
\hline & & Merak Ettiklerimiz \\
\hline & & Bisiklet Zamanı \\
\hline & & Yemek, İçmek ve Sindirmek \\
\hline & & Vazgeçmeyenlerin Hikâyesi \\
\hline & & Dostluğa Dair \\
\hline & & Sevgi Filozofu Yûnus Emre \\
\hline Sebep-Sonuç & 1 & Su Kirliliği \\
\hline Problem Çözme & 1 & Teknoloji Bağımlılığı \\
\hline Karşılaştırma & 1 & Şimşekler ve Yıldırımlar \\
\hline Tanıtıcı ve sıralama & 3 & $\begin{array}{l}\text { Tarhana'nın Öyküsü } \\
\text { Obezite Hakkında } 10 \text { Soru } 10 \text { Cevap } \\
\text { Cirit }\end{array}$ \\
\hline $\begin{array}{l}\text { Öyküleyici metin yapısı } \\
\text { içeren tanıtıcı metin } \\
\text { yapısı* }\end{array}$ & 3 & $\begin{array}{l}\text { Aziz Sancar } \\
\text { Afyon } \\
\text { Kar Kristallerinin Peşinde Bir Yaşam }\end{array}$ \\
\hline
\end{tabular}

*Bu metinler Şekil 5'teki bilgilendirici ve öyküleyici metinlerin içinde olduğu ve tanıtıcı metinleri de kapsadığı için Tablo 4'te bu metinlere de yer verilmiştir.

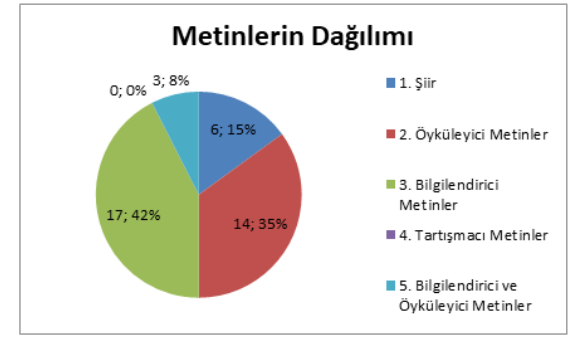

Şekil 5. MEBYT6 Ders Kitabı'ndaki Metinlerin Dağılımı

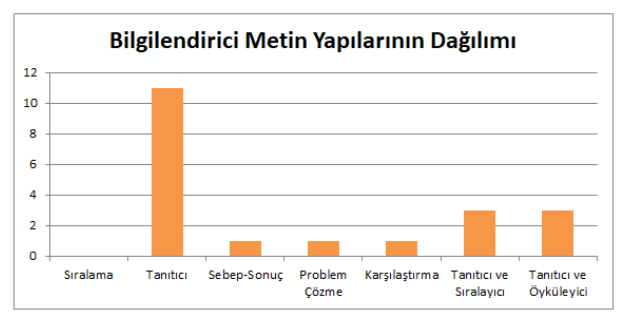

Şekil 6. MEBYT6 Ders Kitabı'ndaki Bilgilendirici Metinlerin Yapılarına Göre Dağılımı

Şekil 5'te görüldüğü gibi MEBYT6 Ders Kitabı'nda yer alan 40 metin (24 okuma, 8 dinleme, 8 serbest okuma metni) incelendiğinde bu metinlerden \%15inin $(f=6)$ şiir, \%35'inin ( $f=14)$ öyküleyici metin, $\% 42$ 'sinin ( $f=17$ ) bilgilendirici metin ve $\% 8$ 'inin $(f=3)$ bilgilendirici ve öyküleyici metin yapılarının birlikte kullanıldığı karma metinlerden oluştuğu görülmektedir. Tablo 4 ve Şekil $6^{\prime}$ da görüldüğü gibi araştırmanın esas amacını oluşturan bilgilendirici metinler açısından bakıldığında büyük bir oranda tanıtıcı metin yapılarına $(f=11)$ yer verildiği, sebep-sonuç $(f=1)$, problem çözme $(f=1)$ ve karşılaştırma $(f=1)$ metin yapılarına sınırlı sayıda yer verildiği görülmektedir.

Bilgilendirici metinlere büyük bir oranda yer verilen MEBYT6 Ders Kitabı'ndaki Su Kirliliği isimli okuma metninde su kirliliğinin ne olduğu tanımlandıktan sonra su kirliliğinin nedenleri ve sonuçları 
üzerinde durulmuştur. Bu doğrultuda sebep-sonuç metinlerinde olduğu gibi ilk paragrafta su kirliliğinin ne olduğu tanımlanmıştır. Yazar "Su kirliliği, genel olarak insanların neden olduğu etkenlerden dolayı suların kalitesinin azalması veya kullanılmaz hâle gelmesidir." cümlesiyle su kirliliğini tanımlama yoluna gitmiştir. Ardından su kirliliğinin nedenlerini açıklamıştır. Bu nedenler arasında konutlar, endüstri kuruluşları, termik santraller, toprak erozyonu gibi süreçleri ve maddelerini sıralamıştır. Metnin ilerleyen bölümlerinde daha detaylı bir şekilde yine su kirliliğinin nedenlerini sıralayarak verdikten sonra "su yüzüne çıkan gerçekler" ve "neler oluyor" alt başlıkları altında su kirliliğinin sonuçlarını açıklamıştır. Metinde "nedenleri, sonuçları, etkile-, ve-, ayrıca, zarar ver-," gibi bağlantı ögelerinden ve belirleyici ifadelerden yararlanmıştır.

Teknoloji Bağımlılığı okuma metninde problem çözme metinlerinde olduğu gibi önce teknoloji bağımlılığı tanımlanmıştır. Ardından "Bağımlıığın belirtileri nelerdir?” alt başlığı ile bağımlılığın nedenleri üzerinde durulmuştur. Daha sonra da "Kendimizi teknoloji bağımlılığından nasıl koruyabiliriz?" alt başlığı ile bu bağımlılı̆ın giderilmesine yönelik çözüm yolları sunulmuştur. Metinde "sorun, neden, çözüm, belirti, ilk yapılacak şey" gibi belirleyici sözcükler kullanılmıştır.

Şimşekler ve Yıldırımlar başlıklı serbest okuma metninde önce pozitif elektrik enerjisi özellikleri üzerinde durulmuştur. Ardından karşılaştırma metin yapılarında görüldüğü üzere iki kavram, şimşekler ve yıldırımlar, birbiriyle karşılaştırılmıştır. Metinde "ama, eğer, fakat, yoksa, farklı şeylerdir, ancak, işte" gibi bağlama ögeleri ve belirleyici sözcüklerden yararlanılarak dilsel yapı güçlendirilmiştir.

Illgili ders kitabındaki metinlerde yalın bir yapı olarak sıralayıcı metin yapısına yer verilmediği tespit edilmiştir. Bununla birlikte üç metinde hem sıralayıcı hem de tanıtıcı metinlerin bir anlatım biçimi ve düşünceyi geliştirme yolu olmanın ötesinde bir yapı olarak kullanıldığı dikkati çekmektedir. Kitapta yer alan Tarhana'nın Öyküsü başlıklı okuma metni bunun tipik bir örneğidir. Metinde öncelikle tanıtıcı metin yapısından yararlanılarak tarhana kelimesinin kökeni, tarhananın geleneksel kültürdeki yeri, yörelere göre değişen özellikleri, kurutulma süreci gibi özellikleri tanıtılıştır. Ardından tarhana çorbasının hazırlanışı tipik bir sıralama metin yapısıyla okuyucuya aktarılmıştır. Bu doğrultuda bu metinlerin girişik bilgilendirici metinler olarak nitelendirilebilir.

Bu ders kitabında dikkati çeken özelliklerden biri, bir önceki ders kitabında olduğu gibi bilgilendirici metin yapılarından biri olan tanıtıcı metin yapısının ve öyküleyici metin yapısının bir arada kullanılmasıdır. Bir anlatım biçimi ve düşünceyi geliştirme yolu olmanın ötesinde üç metinde (Aziz Sancar, Afyon, Kar Kristallerinin Peşinde Bir Yaşam) hem öyküleyici metin yapısının hem de tanıtıcı metin yapısının iç içe geçtiği görülmektedir. Örneğin Aziz Sancar başlıklı okuma metninin esas yazılma amacı bilime büyük katkılar sunan Aziz Sancar'ı tanıtmak, Aziz Sancar hakkında bilgi vermektir. Yalnız Sancar'ın bilime sunduğu bu katkılar, karakterin dilinden ve olaylar silsilesi hâlinde okuyucuya sunulmuş, böylece öğrencilerin metni anlamlandırma süreçlerine katkı sağlanmaya çalışılmıştır.

\section{ÖYT7 Ders Kitabı'ndaki bilgilendirici metinler ve yapılarına ilişkin bulgular}

ÖYT7 Ders Kitabı'ndaki bilgilendirici metinler ve yapılarının dağılımına ilişkin bulgular, Tablo 5, Şekil 7 ve Şekil 8'de sunulmuştur.

Tablo 5. ÖYT7 Ders Kitabı'ndaki Bilgilendirici Metin Yapıları

\begin{tabular}{lll}
\hline Bilgilendirici Metin Yapısı & $\mathrm{f}$ & Metinler \\
\hline Sıralama & - & - \\
\hline Tanıtıcı & 9 & Anadolu Üstüne \\
& Ankara \\
& Dünya Kadar Plastik \\
& Anadolu Davulu \\
& Türkiye'de Geleneksel Sanatlar \\
& iletişim Becerilerimiz \\
\hline
\end{tabular}




\begin{tabular}{|c|c|c|c|}
\hline & & & $\begin{array}{l}\text { Islıkla Haberleşenler } \\
\text { Elinizin Altındaki Dünya } \\
\text { Türk Havacılığına Adanmış Bir Ömür: } \\
\text { Vecihi Hürkuş }\end{array}$ \\
\hline Sebep-Sonuç & & 1 & Müziği Neden Severiz? \\
\hline Problem Çözme & & - & - \\
\hline Karşılaştırma & & - & - \\
\hline $\begin{array}{l}\text { Öyküleyici metin } \\
\text { içeren tanıtıcı } \\
\text { yapısı* }\end{array}$ & $\begin{array}{l}\text { yapısı } \\
\text { metin }\end{array}$ & 3 & $\begin{array}{l}\text { İstiklâl Marşı'nın Kabulü } \\
\text { Ampulün IIlk Yanışı } \\
\text { İbni Sina }\end{array}$ \\
\hline
\end{tabular}

*Bu metinler Şekil 7'deki bilgilendirici ve öyküleyici metinlerin içinde olduğu ve tanıtıcı metinleri de kapsadığı için Tablo $5^{\prime}$ te bu metinlere de yer verilmiştir.

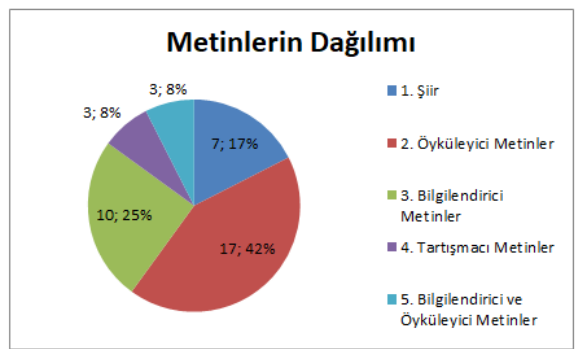

Şekil 7. ÖYT7 Ders Kitabı'ndaki Metinlerin Dağılımı

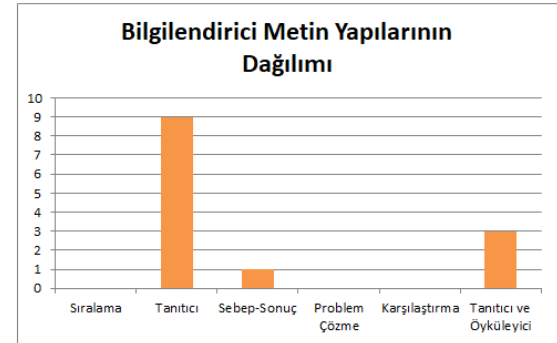

Şekil 8. ÖYT7 Ders Kitabı'ndaki Bilgilendirici Metinlerin Yapılarına Göre Dağılımı

Şekil 7'de görüldüğü gibi ÖYT7 Ders Kitabı'nda yer alan 40 metin (24 okuma, 8 dinleme, 8 serbest okuma metni) incelendiğinde bu metinlerden $\% 17$ 'sinin ( $f=7)$ şiir, $\% 42$ 'sinin ( $f=17$ ) öyküleyici metin, \%25'inin ( $f=10$ ) bilgilendirici metin, \%8'inin ( $f=3$ ) tartışmacı metin ve \% $8^{\prime}$ inin ( $f=3$ ) bilgilendirici ve öyküleyici metinlerin birlikte kullanıldığı karma yapıda metinlerden oluştuğu görülmektedir. Tablo 5 ve Şekil 8'de görüldüğü gibi araştırmanın esas amacını oluşturan bilgilendirici metinler açısından bakıldığında daha çok tanıtıcı metin yapılarına $(f=9)$ ve çok sınırlı olmak üzere sebep-sonuç $(f=1)$ metin yapılara yer verildiği görülmektedir. Sıralama, problem çözme ve karşılaştırma metin yapılarına yer verilmeği tespit edilmiştir.

Islıkla Haberleşenler okuma metni tanıtıcı metin yapısıyla kaleme alınmıştır. Metinde öncelikle insanın sesini duyamadığı zamanlarda kullanılan ıslık ve Giresun'un Çanakçı ilçesindeki Kuşköy'de ortaya çıkan ısık dili ve burada konuyla ilgili düzenlenen festivaller tanıtılmıştır. Ardından bilim insanlarının ıslık dili üzerine yaptığı araştırmalar ve dünyanın farklı bölgelerinde ıslıkla haberleşen toplumlar tanıtılmıştır. Metinde "genellikle, böylece, var, da, bu nedenle, böylece, bunlardan biri, bu amaçla, belirttiğine göre, çünkü" gibi bağlama ögelerinden ve belirleyici sözlerden yararlanılmıştır.

Müziği Neden Severiz? başlıklı serbest okuma metni sebep-sonuç metin yapısıyla kaleme alınmıştır. Bu metinde yapıya uygun olarak öncelikle müzik çok kısa bir şekilde tanımlanmıştır. Ardından Kanadalı bir grup bilim insanının araştırmasından hareketle insanların müziği sevme nedenleri açıklanmıştır. Daha sonra da müzik dinlemenin etkilerine yer verilmiştir. Metinde "nedeni, çünkü, böylece, işte, bu sonuçlar" gibi bağlama ögelerinden ve belirleyici sözlerden yararlanılmıştır.

EYT6 ve MEBYT6 ders kitaplarında olduğu gibi bu ders kitabında da bilgilendirici metin yapılarından biri olan tanıtıcı metin yapısının ve öyküleyici metin yapısının bir arada kullanıldı̆̆ı görülmüştür. Bir anlatım biçimi ve düşünceyi geliştirme yolu olmanın ötesinde üç metinde (İstiklâl Marşı'nın Kabulü, Ampulün ilk Yanışı ve ibni Sina) hem öyküleyici metin yapısının hem de tanıtıcı metin yapısının iç içe geçtiği görülmektedir. Örneğin İbni Sina'nın başarılarını tanıtmak amacı olan ibni Sina metni çizgi roman şeklinde hazırlanmış, olaylar örgüsü hâlinde sunulmuştur. 


\section{MEBYT7 Ders Kitabı'ndaki Bilgilendirici Metinler ve Yapılarına ilişskin Bulgular}

MEBYT7 Ders Kitabı'ndaki bilgilendirici metinler ve yapılarının dağılımına ilişkin bulgular, Tablo 6, Şekil 9 ve Şekil 10’da sunulmuştur.

Tablo 6.

MEBYT7 Ders Kitabı'ndaki Bilgilendirici Metin Yapıları

\begin{tabular}{|c|c|c|}
\hline Bilgilendirici Metin Yapısı & $f$ & Metinler \\
\hline Siralama & 1 & $\begin{array}{l}\text { Başarıya Gitmek mi, Başarıyı Çekmek } \\
\text { mi? }\end{array}$ \\
\hline Tanıtıcı & 9 & $\begin{array}{l}\text { Okumanın İşlevi } \\
\text { Okumak Düşünmek İçindir } \\
\text { Adını Göklere Yazdıran Çocuk } \\
\text { Karagöz Nedir? } \\
\text { Anadolu'da Kilim Demek } \\
\text { Karlı Dağların Arkadaşı Ol } \\
\text { Âşık Veysel Şatıroğlu } \\
\text { Geleneksel Türk Sanatlarından Ebru } \\
\text { Yaşayan İnsan Hazineleri }\end{array}$ \\
\hline Sebep-Sonuç & 1 & İki Tekerlekli Özgürlük \\
\hline Problem Çözme & 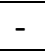 & - \\
\hline Karşılaştırma & - & - \\
\hline $\begin{array}{l}\text { Öyküleyici metin yapısı } \\
\text { içeren tanıtıcı metin } \\
\text { yapısı* }\end{array}$ & 4 & $\begin{array}{l}\text { Çiçek Dürbünü } \\
\text { Mevlânâ Celâleddîn-i Rûmî } \\
\text { Bilim İnsanı Öyküleri } \\
\text { Gize }\end{array}$ \\
\hline
\end{tabular}

*Bu metinler Şekil 9'daki bilgilendirici ve öyküleyici metinlerin içinde olduğu ve tanıtıcı metinleri de kapsadığı için Tablo 6'da bu metinlere de yer verilmiştir.

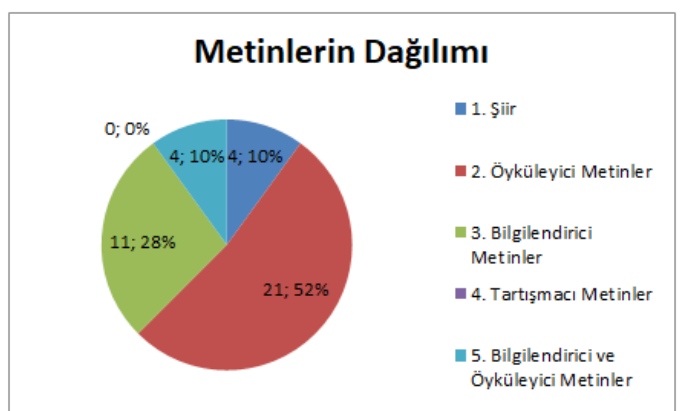

Şekil 9. MEBYT7 Ders Kitabı'ndaki Metinlerin Dağılımı

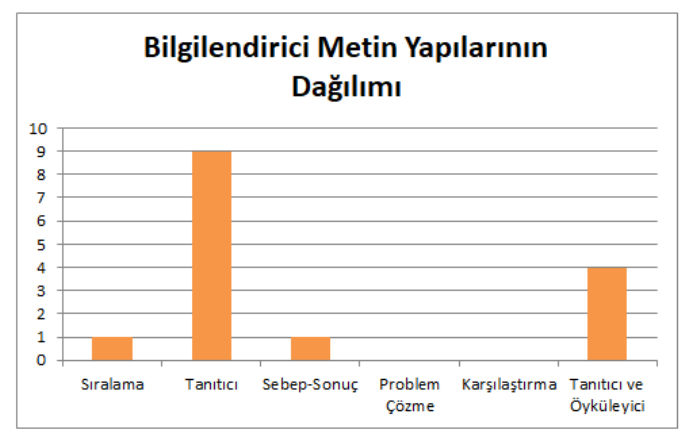

Şekil 10. MEBYT7 Ders Kitabı'ndaki

Bilgilendirici Metinlerin Yapılarına Göre Dağılımı

Şekil 9'da görüldüğü gibi MEBYT7 Ders Kitabı'nda yer alan 40 metin (24 okuma, 8 dinleme, 8 serbest okuma metni) incelendiğinde bu metinlerden $\% 10$ 'unun ( $f=4)$ şiir, $\% 52$ 'sinin ( $f=21$ ) öyküleyici metin, $\% 28^{\prime}$ inin $(f=11)$ bilgilendirici metin ve \%10'unun ( $\left.f=4\right)$ bilgilendirici ve öyküleyici metinlerin birlikte kullanıldığı oluşan karma metinlerden oluştuğu görülmektedir. Tablo 6 ve şekil 10'da görüldüğü gibi araştırmanın esas amacını oluşturan bilgilendirici metinler açısından bakıldığında önceki bulgulara benzer şekilde daha çok tanıtıı metin yapılarına $(f=9)$ ve çok sınırlı olmak üzere sebep-sonuç $(f=1)$ ve sıralama $(f=1)$ metin yapılarına yer verildiği görülmektedir. Problem çözme ve karşılaştırma metin yapılarına yer verilmeği tespit edilmiştir.

Başarıya Gitmek mi, Başarııı Çekmek mi? başlıklı okuma metninde hedefe ulaşmak ve başarılı olmak için yapılması gerekenler listeleme yoluyla sıralanmıştır. Metinde yazar sıralama metin 
yapısında olduğu gibi “Hedefine ulaşmak için bir kapıdan geçmen gerekiyor ama o kapı kapalı. Önce o kapıyı bir kez çal ve sonra oluruna bırak. Bu acemiliğin yoludur. Kapı açılmadı mı aynı kapıyı kırk kez daha çal!", "Kırk farklı kapıyı kırk kez çal!", "Hâlâ istediğine ulaşamadıysan son olarak zamanı kullan.", "Uzun zamandır hiçbir şey değişmediyse ve artık beklemek istemiyorsan o zaman tersine bir strateji izlemelisin!", "Yeni stratejin şu: Kapıyı çalan değil, kapısı çalınan olacaksın" gibi öğütlerini sıralamıştır. Bu bağlamda metinde emir kipiyle oluşturulmuş yönergeler sunularak dilsel yapı güçlendirilmiştir. Ayrıca metinde "önce, sonra, bu defa, bu kez, hâlâ" gibi bağlama ögelerinden ve belirleyici sözlerden yararlanılmıştır.

iki Tekerlekli Özgürlük metninde sebep-sonuç metin yapısı kullanılmıştır. Bu doğrultuda metinde öncelikle hoş bir zaman geçirmenin yollarından biri olan bisiklet keyfi tanıtılmıştır. Ardından bisiklet kullanmanın sağlık ve eğlenme olmak üzere iki temel faydasına değinilmiştir. Daha sonra da bisiklet kullanmanın sonuçları üzerinde durulmuştur. Metinde "neden, için, sonuç, ama" gibi bağlama ögelerinden faydalanılmıştır.

EYT6, MEBYT6 ve ÖYT7 ders kitaplarında görüldüğü gibi bu ders kitabında da bilgilendirici metin yapılarından biri olan tanıtıcı metin yapısının ve öyküleyici metin yapısının bir arada kullanıldığı tespit edilmiştir. Bir anlatım biçimi ve düşünceyi geliştirme yolu olmanın ötesinde dört metinde (Çiçek Dürbünü, Mevlânâ Celâleddîn-i Rûmî, Bilim Insanı Öyküleri, Gize) hem öyküleyici metin yapısının hem de tanıtıcı metin yapısının iç içe geçtiği görülmektedir. Örneğin gezi türünde kaleme alınmış olan Gize metninde Keops, Kefren ve Mikerinos piramitlerinden özellikle Keops piramidi tanıtılmış, piramitlerin planlanması ve özellikleri üzerinde durulmuştur. Piramitleri tanıtma amacıyla kaleme alınmış olan eserde yazar bir rehber eşliğinde yapılan gezide öyküleyici unsurlara başvurmuştur. Yazar piramidin içine girenlerin kan ter içinde kalmasından, rehberin kendilerini bir tepeye götürmesinden bahsetmiş ve kendi duygularına yer vermiştir. Böylece metnin esas yazılma amacının tanıtma olduğu görülmekle birlikte hem tanıtıcı hem öyküleyici metin yapısına dayandığı tespit edilmiştir.

\section{MEBYT8 Ders Kitabı'ndaki Bilgilendirici Metinler ve Yapılarına ilişsin Bulgular}

MEBYT8 Ders Kitabı'ndaki bilgilendirici metinler ve yapılarının dağılımına ilişkin bulgular, Tablo 7, Şekil 11 ve Şekil 12'de sunulmuştur.

Tablo 7.

MEBYT8 Ders Kitabı'ndaki Bilgilendirici Metin Yapıları

\begin{tabular}{|c|c|c|}
\hline Bilgilendirici Metin Yapısı & $f$ & Metinler \\
\hline Siralama & - & - \\
\hline Tanıtıcl & 9 & $\begin{array}{l}\text { Atatürk ve Müzik } \\
\text { Gündelik Hayatımızda E-Hastalıklar } \\
\text { Parktaki Bilim } \\
\text { Eski Çağlardan Beri Dişlerimize Çok } \\
\text { İyi Baktık } \\
\text { Karanlığın Rengi Beyaz } \\
\text { Eşref Saat } \\
\text { Bir Fincan Kahve } \\
\text { Hava Kirliliği } \\
\text { Zeytinyağı Üretimi }\end{array}$ \\
\hline Sebep-Sonuç & - & - \\
\hline Problem Çözme & - & - \\
\hline Karşılaştırma & 1 & İyimserlik ve Kötümserlik Üzerine \\
\hline $\begin{array}{l}\text { Öyküleyici metin yapısı } \\
\text { içeren tanıtıcı metin yapısı* }\end{array}$ & 3 & $\begin{array}{l}\text { Simit ve Peynir'le Bilim İnsanı } \\
\text { Öyküleri } \\
\text { Peri Bacaları } \\
\text { Canberra (Kanberra) }\end{array}$ \\
\hline
\end{tabular}


*Bu metinler Şekil 11'deki bilgilendirici ve öyküleyici metinlerin içinde olduğu ve tanıtıcı metinleri de kapsadığı için Tablo 7'de bu metinlere de yer verilmiştir.

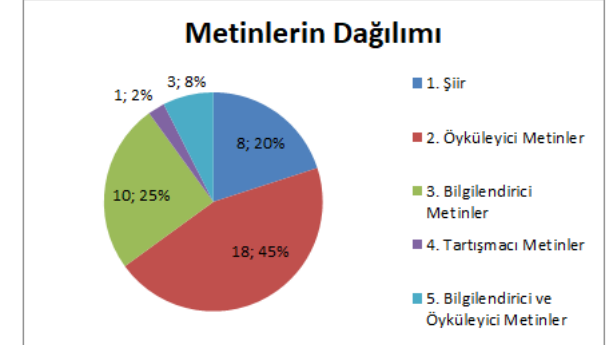

Şekil 11. MEBYT8 Ders Kitabı'ndaki Metinlerin Dağılımı

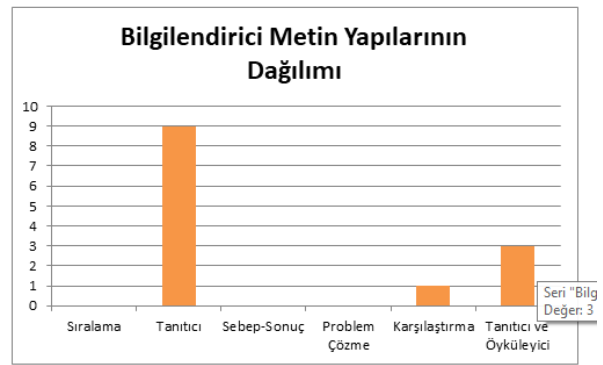

Şekil 12. MEBYT8 Ders Kitabı'ndaki Bilgilendirici Metinlerin Yapılarına Göre Dağılımı

Şekil 11'de görüldüğü gibi MEBYT8 Ders Kitabı'nda yer alan 40 metin (24 okuma, 8 dinleme, 8 serbest okuma metni) incelendiğinde bu metinlerden \%20'sinin ( $f=8)$ şiir, \%45'inin ( $f=18$ ) öyküleyici metin, \%25'inin ( $f=10)$ bilgilendirici metin, \%2'sinin ( $f=1)$ tartışmacı metin ve \%8'inin ( $f=3$ ) bilgilendirici ve öyküleyici metinden oluşan karma metinlerden oluştuğu görülmektedir. Tablo 7 ve Şekil 12'de görüldüğü gibi araştırmanın esas amacını oluşturan bilgilendirici metinler açısından bakıldığında daha çok tanıtıcı metin yapılarına $(f=9)$ ve çok sınırlı olmak üzere karşılaştırma $(f=1)$ metin yapılarına yer verildiği görülmektedir. Sıralama, sebep-sonuç ve problem çözme metin yapılarına yer verilmediği tespit edilmiştir.

MEBYT8 Ders Kitabı'ndaki tanıtıcı metinlerden birine Gündelik Hayatımızda E-Hastalıklar okuma metni örnek gösterilebilir. Çağımızdaki dijital bağımlılık türlerinin tanıtıldığı metinde phubbing (fabbing), siberkondria (saybırkondiria), elektronik uykusuzluk, fantom (fantım) vibrasyon gibi ehastalıklar ayrı paragraflarda açıklanmakta, bunlara ilişkin detaylı bilgiler sunulmaktadır. Metinde "...dir (e hastalıktır vb.) , ... olarak ifade edebileceğimiz, da, işte bu durum, böylece, dolayısıyla" gibi bağlama ögelerinden ve belirleyici ifadelerden yararlanılmıştır.

Ders kitabında tek karşılaştırma metni olarak yer alan lyimserlik ve Kötümserlik okuma metninde iyimser ve kötümser insanların özellikleri karşılaştırılmaktadır. Metinde önce insanların iyimserler ve kötümserler olarak ikiye ayrıldığı üzerinde durulmuştur. İkinci paragrafta kötümser insanlar betimlenmiş, üçüncü paragrafta iyimser insanların özelliklerine değinilmiştir. ilerleyen paragraflarda iyimserlik ve kötümserliği karşılaştıran yazar, bireyin bu iki özelliği de dengelemesi gerektiğini vurgulamıştır. Metinde "iki öbekte ele alınır, ... kadar...da, ya... ya da, sadece, hiç de, yoksa, daha çok, kimi durumlarda... kimi durumlarda ise, genel kanıya göre, gibi, daha iyi, her iki tarafın da, ortak" gibi bağlama ögelerinden ve belirleyici sözlerden yararlanılmıştır.

EYT6, MEBYT6, ÖYT7 ve MEBYT7 ders kitaplarında görüldüğü gibi bu ders kitabında da bilgilendirici metin yapılarından biri olan tanıtıcı metin yapısının ve öyküleyici metin yapısının bir arada kullanıldığı tespit edilmiştir. Bir anlatım biçimi ve düşünceyi geliştirme yolu olmanın ötesinde üç metinde (Simit ve Peynir'le Bilim Insanı Öyküleri, Peri Bacaları, Canberra (Kanberra)) hem öyküleyici metin yapısının hem de tanıtııı metin yapısının iç içe geçtiği görülmektedir. Peri Bacalarının tanıtılmasının amaçlandığı Peri Bacaları okuma metninde öncelikle ilgili bölge tanıtılmış, ardından burayla ilgili bir efsaneye yer verilerek yaşanan olaylar sıralanmıştır.

\section{Incelenen Tüm Ders Kitaplarındaki Bilgilendirici Metinler ve Yapılarına ilişskin Bulgular}

Incelenen tüm ders kitaplarındaki bilgilendirici metinlerin ve yapılarının dağııımına ilişkin bulgular, Tablo 8, Şekil 13 ve Şekil 14'te sunulmuştur.

Tablo 8.

Çalışma Materyalinde Yer Alan Bilgilendirici Metin Yapıları

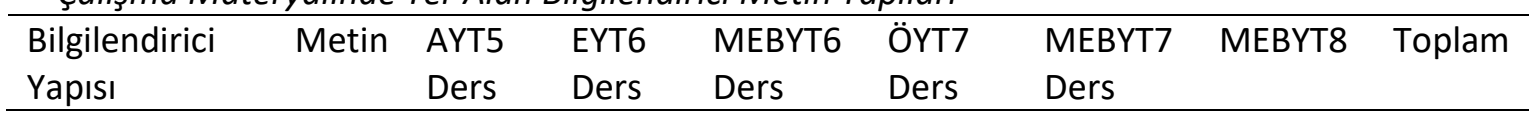


Türkçe Ders Kitaplarındaki Bilgilendirici Metinlerin ve Yapılarının İncelenmesi Üzerine Bir Araştırma

\begin{tabular}{|c|c|c|c|c|c|c|c|}
\hline & Kitabı & Kitabı & Kitabı & Kitabı & Kitabı & & \\
\hline Sıralama & 1 & - & - & - & 1 & - & 2 \\
\hline Tanıtıcı & 8 & 5 & 11 & 9 & 9 & 9 & 51 \\
\hline Sebep-Sonuç & 2 & - & 1 & 1 & 1 & - & 5 \\
\hline Problem Çözme & - & - & 1 & - & - & - & 1 \\
\hline Karşılaştırma & - & - & 1 & - & - & 1 & 2 \\
\hline Tanıtıcı ve Sıralayıcı & - & - & 3 & - & - & - & 3 \\
\hline $\begin{array}{l}\text { Öyküleyici metin yapısı } \\
\text { içeren tanıtıcı metin } \\
\text { yapısı* }\end{array}$ & - & 2 & 3 & 3 & 4 & 3 & 15 \\
\hline $\begin{array}{l}\text { Öyküleyici metin yapısı } \\
\text { içeren sıralayıcı metin } \\
\text { yapısı* }\end{array}$ & 1 & - & - & - & - & - & 1 \\
\hline
\end{tabular}
için Tablo 8'de bu metinlere de yer verilmiştir.

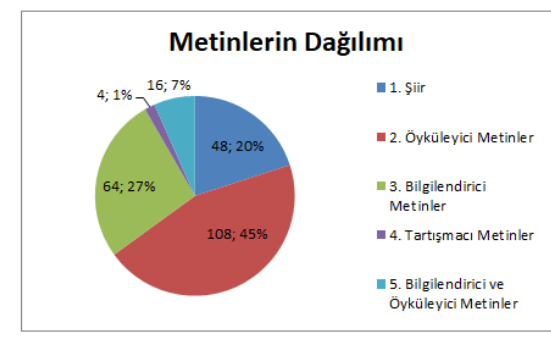

Şekil 13. Çalışma Materyalindeki Metinlerin Dağılımı

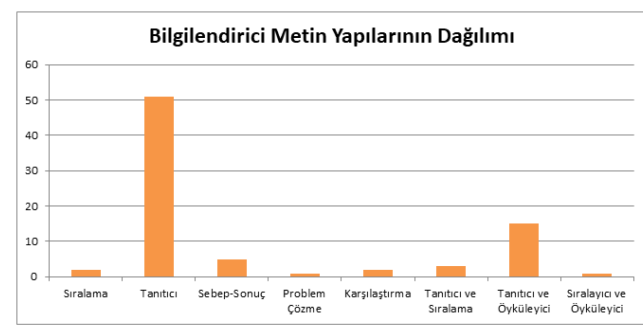

Şekil 14. Çalışma Materyalindeki Bilgilendirici Metinlerin Yapılarına Göre Dağılımı

Şekil 13'te görüldüğü gibi incelemeye tâbi tutulan altı ders kitabındaki 240 metin (144 okuma, 48 dinleme, 48 serbest okuma metni) incelendiğinde bu metinlerden \%20'sinin ( $f=48$ ) şiir, \%45'inin ( $f=108$ ) öyküleyici metin, \%27'sinin ( $f=64)$ bilgilendirici metin, $\% 1^{\prime}$ inin $(f=4)$ tartışmacı metin ve $\% 7$ 'sinin ( $f=16$ ) bilgilendirici ve öyküleyici metinden oluşan karma yapıda metinlerden oluştuğu görülmektedir. Tablo 8 ve Şekil 14'te görüldüğü gibi araştırmanın esas amacını oluşturan bilgilendirici metinler açısından bakıldığında ders kitaplarında en çok tanıtıı metin yapılarına $(f=51)$ yer verildiği tespit edilmiştir. Sıralayıcı $(f=2)$, sebep-sonuç $(f=5)$, problem çözme $(f=1)$, karşılaştırma $(f=2)$ metin yapılarına son derece sınırı sayıda yer verildiği görülmüştür. Bununla birlikte MEBYT6 ders kitabında tanıtıcı ve sıralayııı metin yapılarının iç içe geçtiği karma yapılı üç metnin yer aldığı belirlenmiştir.

AYT5 Ders Kitabı haricinde diğer ders kitaplarının tamamında tanıtıcı metin yapısının ve öyküleyici metin yapısının bir arada kullanıldığı tespit edilmiştir. Bir anlatım biçimi ve düşünceyi geliştirme yolu olmanın ötesinde toplam 15 metinde bilgilendirici metin yapılarından tanıtıcı metin yapısının yanı sıra öyküleyici metin yapısından faydalanılan karma yapılı metinlerin yer aldığı görülmüştür. Yalnızca AYT5 ders kitabında bir metinde de sıralayıcı metin yapısı ile öyküleyici metin yapısının bir arada kullanıldığı tespit edilmiştir.

Belirtilenlerin yanı sıra ders kitaplarında yer alan bilgilendirici metinler göz önünde bulundurulduğunda bilgilendirici metinlerin çeşitliği ve zenginliği açısından MEBYT6 Ders Kitabı'nın diğer kitaplardan daha başarılı olduğu dikkati çekmektedir. Ayrıca MEB Yayınları'nın özel yayınevlerinden bu konuda daha hassas olduğu söylenebilir.

\section{Tartışma, Sonuç ve Öneriler}

Metinlerin öğrenciler tarafından kullanılmasıyla anlam üretimi başlar. Okuma ve dinleme metinleri açısından bakıldığında metnin nasıl kullanılacağı ve nasıl duyulacağı verimli bir Türkçe dersi açısından çok önemlidir. Kimi metinler, öğrenciler tarafından çok kolay algılanırken kimi metinler ise cümleler arası işlemlerin yoğunluğu sebebiyle algılanamamaktadır. Aslında öğrenci okul ortamına girdiği andan itibaren sıklıkla tahkiye yapısındaki metinlerle ve anlatımlarla karşılaşmakta ancak bilgi 
verici metinleri branş dersleri aracılığıyla tanımaktadırlar, dolayısıyla bilgilendirici metin yapısına yabancı kalmaktadırlar. Oysaki bilgilendirici/öğretici metinler kullanmalık metinler olmakla birlikte çok katmanlı yapıları da yoktur ve anlaşılmak için de çok yönlü bir çabaya intiyaç yoktur. Düşünce odaklı oldukları için de bir belirsizlik ya da gizlilik söz konusu değildir. Burada aslında hem metni okutanlar (öğretmenler) hem de metni kullananlar (öğrenciler) açısından var olan iki genel sorun şudur: 1-Metin yapısı, metin türü, metin tipi, metin tonu ve anlatım özellikleri kavramlarının tam olarak anlaşılamamış olması 2-Farklı metin yapılarına sahip türlere yeterince yer verilmemesi

Öğrenciler, bütün derslerde olduğu gibi Türkçe derslerinde de okudukları metinlerin somut karşılıklarını görmek isterler. Burada temel sorun; metnin soyut, söylemin ise somut olduğunun okuyucu durumundaki öğrenci tarafından algılanmamış olmasıdır. Hâlbuki bu iki kavramın (metin ve söylem) özellikle ortaokul 5.sınıftan itibaren kavratılması, öğrencinin her türlü metni okuyup söyleme çevirmesinde (soyuttan somuta geçiş) kolaylık sağlayacaktır. Metin dediğimiz dilsel yapının işleyiş sesi (Rifat, 2011, s. 3) metne bakmayı ve metni yorumlamayı kolaylaştırır. Bu sesi duyabilmek için metni oluşturan cümleler arası ilişkileri, metnin yapısını, metnin türünü, tonunu ve tipini iyi bilmek ve ayırt etmek gerekir. Ne var ki, geçmişten günümüze bu tanımlamalar ve sınıflandırmalarla ilgili ortak bir kanaat oluşmamıştır. Dolayısıyla hâlihazırda öğrenciler, okudukları metinlerin türleri ve yapılarıyla ilgili çelişkiler yaşamaktadırlar. Bu yapıların farkında olmak, "okuyucunun metni anlamasını kolaylaştııırken yazarın da bilgileri bir bütünlük ve ilişki içinde düzenlemesini sağlar" (Temizkan ve Atasoy, 2014, s. 212). Örneğin, Ören, Konuk, Sefer ve Sarıtaş (2017) çalışmalarında; 2006, 2009, 2012 ve 2015 Türkçe Öğretim Programlarında metin türlerini tablolaştırmışlar ve programlarda her yıl için ayrı bir tür tasnifine gidildiğini göstermişlerdir. Bu doğrultuda dört farklı tür tablosuna ulaşmışlardır:

1. Tür tablosu: öyküleyici metin, bilgilendirici metin, şiir

2. Tür tablosu: şiir, hikâye, anı, masal, fabl, deneme, tiyatro, mektup, sohbet (söyleşi), gezi yazısı, biyografi, makale, roman, eleştiri, destan

3. Tür tablosu: hikâye edici metin, bilgi verici metin, şiir

4. Tür tablosu: açıklayıcı, öyküleyici, betimleyici, tartışmacı

Çalışmalarının devamında Ören ve diğerleri (2017) PISA'daki metin türlerini altıya ayırıp özetle şu şekilde sınıflandırmışlardır:

1. Betimleyici/tanımlayıcı metinler (ne sorusunun cevabı, gezi yazısı veya günlükte belirli bir yerin tasviri, katalog, coğrafî bir harita, online uçuş programı, teknik bir kılavuzdaki tasvir, teknik el kitapları, blog, günlük)

2. Öyküleyici metinler (ne zaman, ne sırayla sorularının cevabı, roman, çizgi roman, kısa hikâye, tiyatro, biyografi, kurgusal metinler, bir olayla ilgili gazete haberleri)

3. Bilgilendirici metinler (konu hakkında bilgilendirme, deneme, çevrimiçi ansiklopedi girişi, bilimsel makale, belleğin bir modelini gösteren diyagram, nüfus eğilimi grafiği, kavram haritası, online ansiklopedi sayfası)

4. Tartışmacı metinler (ikna edici ve fikir beyanlı metin türü, editöre mektup, çevrimiçi forum gönderileri, reklam metinleri, internet temelli bir kitap veya film eleştirisi)

5. Yönergeler/tanıtım metinleri (nasıl kurulabileceği ve nasıl kullanılabileceği, reçete, yemek tarifi, işletim sistemi ve yazılım kullanım kılavuzu, ilkyardım süreci diyagramı, dijital bir yazılımın kurulum kılavuzu)

6. Faaliyet metinleri (ilk kez PISA 2009'da kullanılmıştır; anketler, görüşme formları, kayıtlar, banka işlemleri için kullanılan formlar gibi günlük metinler, haber paylaşımı yapan kişisel metin, toplantı için yazı Imış mesaj metinleri, iş e-postaları ve metin mesajları)

Bu bilgiler değerlendirildiğinde metin türü, tipi gibi kavramlar açısından bir birliğin olmadığı görülmektedir. Bu durumun da programlarda ve Türkçe ders kitaplarında karmaşaya sebep olduğu söylenebilir.

Uğur (2017) çalışmasında; bilgilendirici metin türü kavramını kullanıp bunu makale, deneme, fıkra, gezi yazısı, eleştiri, sohbet, biyografi gibi alt türlere ayırmıştır. Çalışmasının hemen devamında bilgilendirici metin yapısı kavramını kullanıp şöyle bir açıklama yapmıştır: "Bilgilendirici türde oluşturulan metinler yazının konusuna, amacına, hedef kitlesine göre farklı yapılarda oluşturulabilir. Bu noktada metin yapısı kavramı devreye girer. Bilgilendirici metin yapısı ile ilgili çalışmalar 
incelendiğinde, bu metin türüyle ilgili üst yapı özelliklerinin öyküleyici türlerdeki kadar net belirlenemediği dikkat çekmektedir (Uğur, 2017, s. 202). "Yazılı metinlerin içeriğinin anlaşııır bir biçimde düzenlenmesini sağlayacak olan yapı, metnin üstyapısı olarak adlandırılır. Bu yapı biçimsel niteliklidir ve bir metnin bütüncül anlamda biçimsel özelliğini ortaya koyar. Bu biçimsel özellik, bir metnin anlamsal içeriğinin belirli bir düzene göre yapılandırılarak okurun, metnin iletisini anlamasını kolaylaştırmayı sağlamak amacıyla okura ipucu ya da yol haritası sunmaya işaret etmektedir" (Ülper, 2008 , s. 9). Düzenli ve planlı bir anlamsal içerik metnin yapısını sağlamlaştırmakla birlikte iletisinin/mesajının okura (öğrenciye) çok daha kolay ulaşmasını sağlar ve üretime geçer. Bu işlemin tüm farklı metin yapıları açısından gerçekleştiği düşünüldüğünde, öğrenci ne kadar farklı tür ve yapıyla karşılaşırsa anlam üretimi o kadar hızlı ve kolay gerçekleşmeye başlayacaktır. Böylece okuma ve dinleme eylemi zor ve sıkıcı olmaktan çıkacak, motivasyon kaynağı hâline gelecektir.

Anlamı oluşturan şemaların işlevsel hâle gelmesi, farklı formlardaki metin yapılarını okumakla ve dinlemekle mümkündür. Örneğin bir metni okurken farklı unsurlara odaklanmak, üst yapının elementlerinden olan tür kavramı ile ilgilidir. "Üst yapı, bir metnin genel anlamını düzenleyen, işlevsel kategorilerden oluşan şematik bir formdur; örneğin bir öykü, anlatı şeması ile düzenlenmiş büyük ölçekli bir yapıyı, bir anlamı ifade eden bir söylemdir, ancak bir anlatı üstyapısı bir öykünün genel içeriği ile aynı değildir, genel içeriği düzenleyen kategorisel yapı ile aynıdır" (Dilidüzgün, 2010, s. 84). Günay'a (2003, s. 188) göre metinler incelenirken onların hangi tür, tip ya da ton içinde bulunduğunu ortaya koymak, bu tiplerin genel özelliği ile incelenen metnin özelliklerini karşılaştırmak üst yapı ile ilgilidir.

“Metnin üst yapısı, metnin türüne göre taşıyacağı varsayılan genel yapısal nitelikleri ve metni oluşturan elementleri belirler. Metnin elementleri hem yazara düşüncelerini tutarlı bir biçimde sunma imkânı sağlar hem de okuyucuya düzenli bilgi ve fikir akışını sağlar" (Coşkun ve Tiryaki, 2011, s. 64). "Yazar, metnini oluştururken amacına ve hedef kitlesine uygun bir tür seçer. Aynı konu, başka türlerde yazıldığında farklı ürünler elde edilir. Yazarın belirlediği tür, onun anlatmak istediğini nasıl ve ne çerçevede anlatacağı ile ilgilidir. Bu anlamda tür kavramı yazara bir çerçeve sunar. Bu çerçevenin kenarlarını da seçilen türün unsurları oluşturur" (Temizkan ve Atasoy, 2014, s. 213).

Yazınsal metinlerin anlam katmanlarında tüm yapıların aktif olması bir yana alandaki bu çelişkilere biraz da olsa ışık tutabilmek amacıyla bu çalışmada Türkçe ders kitaplarındaki temalar altındaki temel okuma, dinleme ve serbest okuma metinleri üst yapı kapsamındaki metin türleri ve yapıları açısından incelenmiş ve görülmüştür ki; incelenen 6 adet Türkçe ders kitabındaki toplam 240 metinden 108 tanesinin öyküleyici metin, 64 tanesinin bilgilendirici metin, 4 tanesinin tartışmacı metin ve 16 tanesinin bilgilendirici ve öyküleyici metinden oluşan karma yapılı metinlerden oluştuğu görülmüştür. Sonuç olarak ders kitaplarında bilgilendirici metinlerin öyküleyici metinlerden az olduğu görülmektedir. Bilgilendirici metin yapıları kendi içinde değerlendirildiğinde araştırma sonucunda bilgilendirici metinlerin 51 tanesi tanıtıc metin yapısıyla oluşturulmuştur. 5 tane sebep-sonuç gösteren metin yapısı, 2 tane sıralayıcı ve karşılaştırmaya dayalı metin yapısı, 1 tane problem çözmeye dayalı metin yapısı kullanılmıştır. Araştırmadan elde edilen bulgular Sulak'ın (2009) yılında yaptığı çalışmanın sonuçları ile örtüşmektedir. Sulak (2009) araştırma sonucunda Türkçe ders kitaplarında bilgilendirici metinlerin genelinde tanımlama metin yapısına yer verildiğini tespit etmiş, diğer yapılara kronolojik sıralama, sebep-sonuç, karşılaştırma-kıyaslama, problem çözme) yeteri kadar yer verilmediğini belirlemiştir. Elde edilen bu sonuçlar süreçte bir değişiklik olmadığını gözler önüne sermektedir. Elde edilen bu bulgular ayrıca göstermektedir ki lise seviyesinden önceki en önemli basamak olan 8. sınıfta 10 tane bilgilendirici metin kullanıldığını bunların sadece 1'inin karşılaştırmaya dayalı metin yapısıyla oluşturulduğunu, problem çözme ve neden sonuç gibi üst düzey bilgilendirici metin yapılarına yer verilmediğini göstermektedir. LGS'nin son eşiği olan bu seviyede öğrencinin öyküleyici metinlerden ve şiirden önce özellikle sebep-sonuç ilişkilerini tespit edebileceği, karşılaştırma yapabileceği, bilgiyi sentezleyebileceği ve problem çözmeye yönlenebileceği metinlere intiyacı vardır. Eğitimde intiyaçlar, yaşanılan coğrafyaya ve eğitim sisteminin dayandığı felsefelerle ilişkilidir. Dolayısıyla bu gerçeklerden hareket edilerek öğrencilere yardımcı olmak ve onların uzun uzun yazılmış metinleri anlayıp anlamlandırabilecekleri seçenekler sunmak gereklidir. 
Bu gerçekler temel alınarak hazırlanacak olan Türkçe ders kitapları hem öğrenciler açısından teşvik edici olacak hem de onları hayata hazırlayacaktır. Örneğin MEBYT6 Ders Kitabı'nda 14 tane öyküleyici metne karşıık 17 tane bilgilendirici metin kullanılmıştır. Hatta bilgilendirici metin yapısı olarak 11 tane tanıtıcı metin, 1 tane sebep-sonuç, problem çözme ve karşılaştırma metni yer almıştır. Bu ders kitabında salt bir sıralayıcı metin olmamakla birlikte, 3 metinde sıralayıcı ve tanıtıcı metin yapısı beraber kullanılmıştır. Bu araştırmanın öznesi olan 6 ders kitabı içinde bilgilendirici metin yapısını merkeze alan tek kitap MEB yayınlarına ait olan 6. sınıf Türkçe ders kitabıdır. Bilgilendirici metin üzerinde titizlikle durulmasının sebebi; öğrenciye bilgiyi nasıl alıp nasıl ve nerede kullanacağına dair ipuçları vermesidir. Uğur'un da (2017) çalışmasında belirttiği gibi "bilgilendirici metinlerin karmaşık yapısına rağmen, okullardaki Türkçe derslerinde özellikle bilgilendirici metin yapılarının yeterince üzerinde durulmadığı dikkat çekmektedir. Metinlerdeki bilgi ve düşüncenin doğru ve net bir biçimde aktarılmasını sağlayan bu yapıların ve işlevlerinin çeşitli örneklerle öğrencilere tanıtılması oldukça önemlidir. Çünkü birey, bilgilendirici metinleri okurken, metin içindeki yapıların farkında olur, bilgilendirici metin unsurlarını en doğru şekilde belirleyebilirse okuduğu metni tam ve doğru olarak anlayabilir" (Uğur, 2017, s. 202). Öğrenciler bilgilendirici metin yapısı farkındalığına sahip olabilirse tutarlı ve etkili metinler yazabilir (Müldür ve Çevik, 2019).

Bunların yanı sıra bu araştırma sonucunda ders kitaplarında karma yapılı metinlere de rastlanmıştır. Bu metinlerin daha çok biyografi, gezi gibi metin türlerinden oluştuğu dikkati çekmektedir. Elde edilen bu bulgu Bozkurt'un (2018) araştırmasıyla benzerlik göstermektedir. Bozkurt özellikle gezi yazısı türündeki metinlerin karma yapılardan oluşabileceğini vurgulamakta, günümüz dünyasında karma metinlere gittikçe daha çok yer verileceğini belirtmektedir. Ayrıca öğrencilere metinlerin türsel olarak sıkı kurallara bağlı olmadığını, kimi türlerin karma yapılardan oluşabileceğini göstermek gerektiğini dile getirmiştir. Ülper (2019) de bir metinde iki farklı yapı kullanılsa bile bunlardan birinin baskın olduğunu belirtmektedir. Mevcut araştırmada incelenen metinlerde karma yapılı metinlerin daha çok öyküleyici ve bilgilendirici metin yapılarından oluştuğu görülmüştür. Bununla birlikte bu metinlerde yazarların esas amacının bilgilendirmek olduğu belirlenmiştir. Elde edilen bu bulgu Ülper'i (2019) de desteklemektedir.

Sonuç olarak bu araştırma doğrultusunda incelenen ders kitaplarında bilgilendirici metinlerin öyküleyici metinlerden az olduğu görülmektedir. Bilgilendirici metin yapıları içinde de tanıtıcı metinlere ağırlıklı olarak yer verildiği; sıralama, sebep-sonuç, problem çözme ve karşılaştırma metin yapılarına sınırlı bir şekilde yer verildiği tespit edilmiştir. Ayrıca bazı bilgilendirici metin yapılarının öyküleyici metin yapısıyla desteklenerek sunulduğu ve karma yapılı metinler oluşturulduğu dikkati çekmektedir. Araştırmanın temel bir amacı olmamakla birlikte tartışmacı metin yapılarına ilişkin bulgu da sunulmuş ve ders kitaplarında tartışmacı metin yapılarına yok denecek kadar az yer verildiği görülmüştür. Tüm bu bilgiler ışığında şu önerilerde bulunulabilinir:

1. Bir metin türünün farklı yapılardan oluşabildiği ve bu farklılığın yazının konusuna, amacına ve hedef kitlesine göre değişebildiği bilgisinden yola çıkılarak Türkçe ders kitaplarına alınacak metin kriterleri gözden geçirilebilir ve bilgilendirici okuma ve dinleme metinlerinin sayıları arttırılabilir.

2. Bilgilendirici türdeki metinlerin iyi anlaşılması, metni oluşturan bilgi ve düşünce birimlerinin doğru şekilde tespit edilmesiyle mümkündür. Bu doğrultuda ilkokuldan itibaren tüm öğrencilerin bu yapılarla karşılaşmaları ve derslerde/ders kitaplarında metin incelemeye yönelik etkinliklere bolca yer verilmesi LGS ve PISA gibi sınavlarda yer alan metin odaklı soruların çözümü için faydalı olacaktır.

3. Öğrenci seviyelerine uygun olarak Türkçe ders kitaplarında aşamalı bir şekilde bilgilendirici ve tartışmacı metin türlerine yer verilmesi öğrenciyi bilgiyi ve bilgiyi üretmeye hazırlaması açısından önemlidir.

4. İncelenen ders kitaplarında tespit edilen bilgilendirici metinlerdeki konularda olduğu gibi bundan sonra hazırlanması planlanan Türkçe ders kitaplarına da yeni dünya düzenine ve gündeme uygun konularda (pandemi, dijital öğrenmeler, e-öğrenme portalları vb.) metin örneklerinin konulmasına özen gösterilebilir. 
5. Türkçe ders kitaplarına alınacak bilgilendirici metinlerin beş farklı yapıda eşit dağılımına dikkat edilmesi öğrenci açısından bilgi zenginliği olabilecek ve öğrenciyi anlam üretimine katkıda bulunmaya davet edebilecektir.

6. Farklı yapılardaki bilgilendirici metinlerin çeşitliliği öğrencileri her sınıf seviyesinde metinler arası okumaya yönlendirebilecektir.

7. Bu çeşitlilik Türkçe öğretmenlerine motivasyon kaynağı olabilecek, onları farklı etkinlikler yapmaya yönlendirebilecektir. Ayrıca dijital platformları daha aktif kullanıp işlevsel olmaya yönlendirecek ve öğretmenleri ve beraberinde öğrencileri durağanlıktan kurtarabilecektir.

8. Türkçe öğretmenliği lisans programında okuyan öğretmen adaylarına birinci sınıftan itibaren metnin büyük, küçük ve üst yapı bilgisinin kazandırılması ve mezuniyet seviyesine gelmiş bir adayın da metnin yapısı, türü, tipi ve tonu gibi başlıklar hakkında karmaşa yaşamayacak duruma gelmiş olması önemlidir. Dolayısıyla Türkçe Öğretmenliği Lisans Programı dersleri içinde yer alan Metindilbilim derslerinde bu konulara ayrıntılı olarak yer verilmesi ve adayların bilgilendirici metinleri okumaya yönlendirilmeleri gerekebilir.

9. Türkçe öğretmenliği lisans programında okuyan öğretmen adayları yazma becerisine yönelik derslerde bilgilendirici metin örnekleri üretebilirler. Böylece göreve başladıklarında ortaokul öğrencilerinin Türkçe derslerinde öğrencilere metin örnekleri sunma konusunda kolaylık yaşayabilirler.

10. Türkçe öğretmenliği lisans programında okuyan Türkçe öğretmeni adaylarına içeriklerin uygun olduğu derslerde, bir yazıda farklı metin yapılarının kullanılabileceğine dair örnekler vermek ve bu şekilde karma yapılarla karşılaşmalarını sağlamak alan yetkinlikleri açısından faydalı olabilecektir.

11. Mevcut araştırmada 2019-2020 eğitim öğretim yılında ortaokul Türkçe derslerinde kullanılan ders kitaplarındaki bilgilendirici metinler ve yapıları incelenmiştir. Farkı bir araştırmada ders kitaplarındaki etkinlik metinlerinde bu metin yapılarının hangi sıklıkla ve nasıl ele alındığını gösteren çalışmalara da yer verilebilir.

12. Bu araştırma belirli bir tarih aralı̆ında yapılmıştır. Bu bağlamda, geçmiş yıllarda yayımlanan ders kitaplarındaki metin yapılarının yanı sıra ileride yayımlanacak olan ders kitaplarındaki metinler de bu yapılar açısından incelenebilir.

13. Farklı bir araştırmada da ihmal edilen ve programda yer bulamayan tartışmacı metin yapılarına odaklanılabilir.

\section{Kaynaklar}

Aktaş, Ş. (2015). Anlatma esasına bağlı edebî metinlerin tahlili. Ankara: Kurgan.

Akyol, H. (1999). Bilgi vermeye dayalı metinler ve öğretimi. Çağdaş Eğitim, 253(7), 7-13.

Akyol, H. (2013). Yeni programa uygun Türkçe öğretim yöntemleri. Ankara: Pegem Akademi.

Armbruster, B. B. (2004). Considerate texts. In D. Lapp, J. Flood, \& N. Farnan (Eds.), Content area reading and learning: Instructional strategies (pp. 47-58). Mahwah, NJ: Erlbaum.

Armbruster, B. B., Anderson, T. H., \& Ostertag, J. (1987). Does text structure/summarization instruction facilitate learning from expository text?. Reading Research Quarterly, 22(3), 331346.

Aydın, ì., \& Torusdağ, G. (2014). Türkçe öğretimi çerçevesinde yazınsal bir metin çözümleme örneği olarak Refik Halit Karay'ın Garip Bir Hediye'si. Uluslararası Türkçe Edebiyat Kültür Eğitim (TEKE) Dergisi, 3(4), 109-134.

Aylanç, M. (2012). Türkçe öğretmeni adaylarının özel öğretim yöntemleri dersi uygulamalarında karşılaştıkları sorunlar: Bilgilendirici ve öğretici metinler örneği. Selçuk Üniversitesi Türkiyat Araştırmaları Dergisi, (31), 333-350.

Baş, B. (2003). Altıncı sınıf Türkçe ders kitaplarında metin türleri üzerine bir inceleme. Türklük Bilimi Araştırmaları, (13), 257-265.

Bilginer, O. (2015). Derin yapı yüzey yapı ilişkisi bağlamında temel dil becerileri üzerine bir analiz çalışması. Ana Dili Eğitimi Dergisi, 3(3), 91-110. 
Bozkurt, B. Ü. (2018). Okuma ve yazma eğitiminde metin türlerini sınıflama sorunsalı ve çoklu/karma türlerin öğretimiyle ilgili öneriler. N. E. Uzun \& B. Ü. Bozkurt (Haz.), Türkçenin eğitimiögrretiminde kuramsal ve uygulamalı çalışmalar-10. içinde (s. 75-99). İstanbul: Okan Üniversitesi.

Coşkun, E. (2007). Yazma becerisi. A. Kırkkılıç \& A. Akyol (Ed.), ilköğretimde Türkçe öğretimi içinde (s. 49-91). Ankara: Pegem Akademi.

Coşkun, E., \& Tiryaki, E. (2011). Tartışmacı metin yapısı ve öğretimi. Mustafa Kemal Üniversitesi Sosyal Bilimler Enstitüsü Dergisi, 8(16), 63-73.

Coşkun, H., \& Çetinkaya, V. (2020). Öğretmen görüşlerine göre Türkçe ders kitaplarındaki metinlerin edebî zevk ve hoşa giderlik açısından değerlendirilmesi. Türkoloji Araştırmaları Dergisi, 1(1), 255-272.

Çiftçi, Ç., Çeçen M., \& A., Melanlığlu, D. (2007). Altıncı sınıf Türkçe ders kitaplarındaki metinlerin okunabilirlik açısından değerlendirilmesi. Elektronik Sosyal Bilimler Dergisi, 6(22), 206-219.

De Beaugrande, R. A. \& Wofgang, U. D. (1981). Introduction to text linguistic. London: Longman Group Company.

Dilidüzgün, Ş., \& Genç, Ş. (2019). Türkçe dersi okuma kazanımlarının metin yapı ölçütlerini karşılama yeterliği: 8. sınıf örneği. Journal of International Social Research, 12(64), 562-571.7

Dilidüzgün, Ş. (2010). Metindilbilim ve Türkçe öğretimi. İstanbul: Morpa.

Duke, N. K. (2000). 3.6 minutes per day: The scarcity of informational texts in first grade. Reading Research Quarterly, 35(2), 202-224.

Günay, D. (2007). Metin bilgisi. İstanbul: Multilingual.

Günay, D. (2013). Söylem çözümlemesi. İstanbul: Papatya.

Güneş, F. (2013a). Türkçede metin öğretimi yerine metinle öğrenme. Adıyaman Üniversitesi Sosyal Bilimler Enstitüsü Dergisi Türkçenin Eğitimi Öğretimi Özel Sayısı, 6(11), 603-637.

Güneş, F. (2013b) Türkçe öğretiminde metin seçimi. Ana Dili Eğitimi Dergisi, 1(1), 1-12.

Güzel Özmen, E. R. (2011). Bir metin yapısı örneği: evrensel dünya problemlerine ilişkin problem çözüm yapısı. Mustafa Kemal Üniversitesi Sosyal Bilimler Enstitüsü Dergisi, 8(16), 49-62.

Hall, K. M., Sabey, B. L., \& McClellan, M. (2005). Expository text comprehension: Helping primarygrade teachers use expository texts to full advantage. Reading Psychology, 26(3), 211-234.

İnceoğlu, Y., \& Çomak, A. N. (2009). Metin çözümlemeleri. İstanbul: Ayrıntı.

İskender, H., \& Yiğit, F. (2015). Küçük yapı düzeyindeki değişimlerin öğrencilerin metni anlamalarına ilişkin görüşleri üzerine etkisi. Mustafa Kemal Üniversitesi Sosyal Bilimler Enstitüsü Dergisi, 12(32), 450-476.

Karatay, H. (2010). Bağdaşıklık araçlarını kullanma düzeyi ile tutarlı metin yazma arasındaki ilişki. Mustafa Kemal Üniversitesi Sosyal Bilimler Enstitüsü Dergisi, 7(13), 373-385.

Kaya, M., \& Kardaş, M. N. (2019). Türkçe öğretmenleri ile Türkçe öğretmeni adaylarının Türkçe ders kitaplarındaki metinlerle ilgili görüşleri. Karadeniz Sosyal Bilimler Dergisi, 11(21), 323-342.

Kıbrıs, S. (2019). Ortaokul (5-8. sınıflar) Türkçe dersi öğretim programı ve ders kitaplarında metin türü farkındalığı. Yüksek Lisans Tezi, Başkent Üniversitesi Eğitim Bilimleri Enstitüsü, Ankara.

Kolaç, E. (2009). İlköğretim Türkçe ders kitaplarında yer alan metinlerin tür açısından değerlendirilmesi. Uluslararası Insan Bilimleri Dergisi, 6(1), 594-626.

Kuzu, T. S. (2004). Etkileşimsel Model'e uygun okuma öğretiminin Türkçe bilgilendirici metinleri anlama düzeyine etkisi. Ankara Üniversitesi Eğitim Bilimleri Fakültesi Dergisi, 37(1), 55-77.

MEB. (2019). 2019-2020 Eğitim Öğretim yılı ders kitapları. Millî Eğitim Bakanlığı Tebliğler Dergisi, 82(2736), 1-63.

Merriam, S. B. (2013). Nitel araştırma: Desen ve uygulama için bir rehber. (S. Turan, Çev.). Ankara: Nobel.

Meyer, B. J. (2003). Text coherence and readability. Topics in Language Disorders, 23(3), 204-224.

Meyer, B. J., \& Freedle, R. O. (1984). Effects of discourse type on recall. American Educational Research Journal, 21(1), 121-143.

Miles, M. B., Huberman, A. M., \& Saldana, J. (2014). Qualitative data analysis: A methods sourcebook. Los Angeles: Sage. 
Miller, T. L., \& Lignugaris-Kraft, B. (2002). The effects of text structure discrimination training on the writing performance of students with learning disabilities. Journal of Behavioral Education, 11(4), 203-230.

Müldür, M., \& Çevik, A. (2019). Ortaokul öğrencilerinin bilgilendirici metin yazma becerilerinin incelenmesi. Anemon Muş Alparslan Üniversitesi Sosyal Bilimler Dergisi, 7(5), 141-149.

Orakçı, A., \& Arhan, S. (2019). 2018 yılı Türkçe dersi (1-8. sınıflar) öğretim programı ile Türkçe ders kitaplarında roman türünün yeri. Millî Eğitim Dergisi, 48(1), 149-176.

Ören, Z., Konuk, S., Sefer, A., \& Sarıtaş, H. (2017). Ortaokul Türkçe öğretim programlarındaki metin türleri ile PISA'daki metin türlerinin karşılaştırılması. In EJER IV. Internatıonal Eurasıan Educatıonal Research Congress Bildiri Kitabı (Vol. 275280).

Özbay, M., \& Çeçen, M. A. (2012). Türkçe Ders Kitaplarında (6-8. Sınıflar) yer alan metinlerin tür ve tema açısından incelenmesi. Dil ve Edebiyat Eğitimi Dergisi, 1(1), 67-76.

Özdemir, E. (2002). Sözlü-yazılı anlatım sanatı (kompozisyon). İstanbul: Remzi.

Piccolo, J. A. (1987). Expository text structure: Teaching and learning strategies. The Reading Teacher, 40(9), 838-847. http://www.jstor.org/stable/20199652?seq=1\#page_scan_tab_contents sayfasından erişilmiştir.

Raphael, T. E., Kirschner, B. W., \& Englert, C. S. (1988). Expository writing program: Making connections between reading and writing. The Reading Teacher, 41(8), 790-795.

Rifat, M. (2011). Metnin sesi. İstanbul: Türkiye İş Bankası.

Siviş, B. T., \& Emiroğlu, S. (2020). illkokul 1-4. sınıflarda okutulan Türkçe ders kitaplarındaki dinleme metinlerinin belirlenen ölçütlere göre incelenmesi. İstanbul Aydın Üniversitesi Eğitim Fakültesi Dergisi, 5(2), 105-136.

Solak, M., \& Yaylı, D. (2009). illköğretim ikinci kademe Türkçe ders kitaplarının türler açısından incelenmesi. Journal Of International Social Research, 2(9), 444-453.

Somuncu, S. (2019). Yazınsallık ve bilgi bağlamında sekizinci sınıf Türkçe ders kitabındaki metinlere ilişkin eleştirel bir inceleme. Adıyaman Üniversitesi Sosyal Bilimler Enstitüsü Dergisi, 11(31), 240-258.

Söylemez, M. (2019). Ortaokul Türkçe ders kitaplarındaki şiirlerin ve şairlerin seçimi üzerine inceleme. Yüksek Lisans Tezi, Pamukkale Üniversitesi Eğitim Bilimleri Enstitüsü, Denizli.

Sulak, S. E. (2009). Ilköğretim okulları 1-5. sınıf Türkçe ders kitaplarında yer alan metinlerin türlerine göre yapılarının değerlendirilmesi. Yüksek Lisans Tezi, Selçuk Üniversitesi Sosyal Bilimleri Enstitüsü, Konya.

Şeref, İ., Karagöz, B., \& Ardıç, İ. K. (2020). Türkçe ders kitaplarındaki okuma metinlerinin metinsellik özellikleri: Lao Tzu'nun 'acele karar vermeyin'öyküsü örneği. Elektronik Sosyal Bilimler Dergisi, 19(73), 92-104.

Taylor, B. M., \& Beach, R. W. (1984). The effects of text structure instruction on middle-grade students' comprehension and production of expository text. Reading Research Quarterly, 19(2), 134-146.

Temizkan, M. (2016). Türkçe dersi öğrenci çalışma kitaplarındaki okuma etkinliklerinin metin yapısı açısından değerlendirilmesi. Ana Dili Eğitimi Dergisi, 4(1), 31-52.

Temizkan, M., \& Atasoy, A. (2014). Türkçe ders kitaplarında yer alan hikâye türündeki metinlerin üst yapı açısından değerlendirilmesi. Uluslararası Türkçe Edebiyat Kültür Eğitim (TEKE) Dergisi, 3(3).

Tok, M., \& Küçük, B. (2014). Öğrenci bilgilendirici metinlerinin kaynakları ve medya unsurlarının değerlendirilmesi. Uşak Üniversitesi Sosyal Bilimler Dergisi, 7(2), 232-247.

Toklu, O. (2009). Dilbilimine giriş. Ankara: Akçağ.

Tompkins, G. E. (2000). Teaching writing: Balancing process and product. New Jersey: Prentice Hall.

Uğur, F. (2017). Ortaokul 7. sınıf öğrencilerinin bilgilendirici metin yapısı unsurlarını belirleme düzeyleri. Mustafa Kemal Üniversitesi Sosyal Bilimler Enstitüsü Dergisi, 14(39), 200-222.

Ülper, H. (2008). Öğrenci metinlerinde üstyapı düzenlenişine ilişkin sorunlar: "giriş" ve "sonuç" bölümleri üzerine bir inceleme. Dil Dergisi, 140, 7-18.

Ülper, H. (2019). Okuma ve anlamlandırma becerilerinin kazandırılması. Ankara: Nobel. 
Üstten, A. U., \& Haykır, T. (2019). Türkçenin yabancı dil olarak öğretiminde metin seçimi. Ahi Evran Üniversitesi Kırşehir Eğitim Fakültesi Dergisi, 20(3), 1633-1652.

Williams, J. P. (2005). Instruction in reading comprehension for primary-grade students a focus on text structure. The Journal of Special Education, 39(1), 6-18.

Yıldırım, A., \& Şimşek, H. (2016). Sosyal bilimlerde nitel araştırma yöntemleri. Ankara: Seçkin.

\section{Extended Abstract}

\section{Introduction}

There are student-based, text-based, strategy-based and task-based variables in understanding of texts for students. (Meyer, 2003, p. 205). These variables are not enough individually for the student to make sense out of the text. Therefore, a strong text structure is one of the basic elements in the meaning of the text. There are functions that exist within the structure of each text. For example, narrative text structures consist of a single structure within a single function, while informative text structures consist of different structures with different functions. In this direction, informative text structures are handled under five headings: description, sequence, causation, problem/soluiton and comparison texts.

Informative texts are the primary source of school and out-of-school learning. Knowing the informative text structure can make it easier for a student to understand how the text they listen to or read is organized in order to retain that text in memory. It can be said that the most important tools for students to recognize their informative text structures are reading and listening texts in Turkish textbooks. In Turkish textbooks, attention should be paid to each of the informative text structures, and teaching should not be carried out solely by focusing on one text structure. Accordingly, the main purpose of this research is to determine the rate of informative texts and structures in Turkish textbooks. In this context, the research will seek answers to the following questions:

1. To what extent are the informative texts included in Turkish textbooks?

2. To what extent is the description text structure included in Turkish textbooks?

3. To what extent is the sequence text structure included in Turkish textbooks?

4. To what extent is the causation text structure included in Turkish textbooks?

5. To what extent is the problem/solution text structure included in Turkish textbooks?

6. To what extent is the comparison text structure included in Turkish textbooks?

It is thought that the current research will guide the authors and book authors who prepare the curriculum by determining the status of Turkish Textbooks. In addition, it is seen in the researches in the textbooks that the texts are mostly examined in terms of literary genre, text type awareness, the distribution of the listening texts, relative to the student, literacy and knowledge, literary pleasure and pleasantness. It has been determined that the studies conducted in terms of text structures are limited. In this context, it is aimed to fill the gap in the literature. In addition, in this study, it is thought that the examination of the textbooks in each grade is important for the scope of the study.

\section{Method}

In this research, basic qualitative research, one of the qualitative research methods, was used. In this study, criterion-based sampling method, which is one of the purposeful sampling methods, was used to determine the study material. In this research, three criterias determined by the researchers were observed in order to determine the limitation and to ensure objectivity and inclusiveness. Accordingly, six Turkish textbooks used in the 2019-2020 academic year are included in the study. The data of this research were collected through document analysis, which is one of the data collection methods in qualitative research.. Descriptive analysis method, one of the qualitative research data analysis, was used in the research. While presenting the distribution of informative 
texts in the current research, the text classification in the theoretical part of the research was used. The texts were analyzed according to the classification of poetry, narrative text, informative text and argumentative text. While examining the informative texts, the five classification mentioned in the theoretical section was also used. In this direction, informative text structures are discussed in the context of description, sequence, cause-effect, problem/solution and comparison classification. On the other hand, since mixed structures are encountered while analyzing the data, these are also presented in the findings section. The reliability of the study was calculated based on the coefficient of reliability among the coders. Text samples are included to increase the transferability of the research.

\section{Result and Discussion}

How to use and hear "reading and listening texts" in Turkish textbooks is very important for an efficient Turkish lesson. Students often encounter texts and narratives in an anchor structure from the moment they enter the school environment, but they get to know the informative texts through branch lessons, so they are unfamiliar with the informative text structure. The two general problems that exist for both readers (teachers) and those who use the text (students) are: 1- The concepts of text structure, text type, text tone and expression features are not fully understood. 2- Types with different text structures are not sufficiently included.

In Ören, Konuk, Sefer and Sarıtaş's (2017) articles; they tabulated the text types in the 2006, 2009, 2012 and 2015 Turkish Teaching Programs and showed that a separate classification was made for each year in the programs. Accordingly, they have reached four different genre tables: 1 . Type chart: narrative text, informative text, poetry 2. Type chart: poetry, story, memory, tale, fable, essay, theater, letter, conversation (conversation), travel writing, biography, article, novel, criticism, saga 3.Type chart: narrative text, informative text, poetry 4.Type chart: descriptive, narrative, descriptive, argumentative

In the continuation of their work, Ören and the others (2017) divided the text types in PISA into six categories and summarized them as follows: 1-Descriptive / descriptive texts 2-Narrative texts 3-Informative texts 4-Discussant texts 5-Guidelines / promotional texts 6-Activity texts

When these and similar classifications in the literature are evaluated, it is seen that there is no unity in terms of concepts such as text type and sort. It can be said that this situation causes confusion in Turkish education programs and Turkish textbooks. In order to shed light on these differences, in the current study, the basic reading, listening and free reading texts under the themes in Turkish textbooks were examined in terms of text types and structures. 108 of the 240 texts in the 6 Turkish textbooks analyzed are 108 texts consisting of annotating text, 64 informative text, 4 are argumentative text and 16 are composite text.

As a result of the research, it was observed that informative texts were less frequently included in all textbooks compared to the annoying texts. In addition, it was determined that the most introduction text structures were involved among the informative text structures in all textbooks, and a very limited number of text structures were included in sequence, cause-effect, problem/solution and comparison text structures. It has been observed that the 6th grade Turkish textbook published by the Ministry of National Education is more sensitive than other Turkish textbooks in terms of providing a variety of informative text structures.

Especially at the 8th grade level, which is the last threshold of LGS, the student needs texts where he can identify, compare, synthesize information and address problem solving, especially before poetry and poetry. Turkish textbooks that will be prepared based on these facts will both be encouraging for students and prepare them for life. 